\title{
Kinetics of $\mathrm{N}_{2} \mathrm{O}$ production and reduction in a nitrate-contaminated aquifer inferred from laboratory incubation experiments
}

\author{
D. Weymann ${ }^{1}$, H. Geistlinger ${ }^{2}$, R. Well ${ }^{3}$, C. von der Heide ${ }^{4}$, and H. Flessa ${ }^{3}$ \\ ${ }^{1}$ Soil Science of Temperate and Boreal Ecosystems, Büsgen-Institute, University of Göttingen, Büsgenweg 2, \\ 37077 Göttingen, Germany \\ ${ }^{2}$ Department of Soil Physics, Helmholtz Centre for Environmental Research - UFZ, Theodor-Lieser-Str. 4, \\ 06120 Halle (Saale), Germany \\ ${ }^{3}$ Institute of Agricultural Climate Research, Johann Heinrich von Thünen-Institute, Bundesallee 50, \\ 38116 Braunschweig, Germany \\ ${ }^{4}$ Institute of Soil Science, Leibniz University of Hannover, Herrenhäuser Str. 2, 30419 Hannover, Germany
}

Received: 3 December 2009 - Published in Biogeosciences Discuss.: 20 January 2010

Revised: 21 May 2010 - Accepted: 8 June 2010 - Published: 20 June 2010

\begin{abstract}
Knowledge of the kinetics of $\mathrm{N}_{2} \mathrm{O}$ production and reduction in groundwater is essential for the assessment of potential indirect emissions of the greenhouse gas. In the present study, we investigated this kinetics using a laboratory approach. The results were compared to field measurements in order to examine their transferability to the in situ conditions. The study site was the unconfined, predominantly sandy Fuhrberger Feld aquifer in northern Germany. A special characteristic of the aquifer is the occurrence of the vertically separated process zones of heterotrophic denitrification in the near-surface groundwater and of autotrophic denitrification in depths beyond 2-3 $\mathrm{m}$ below the groundwater table, respectively. The kinetics of $\mathrm{N}_{2} \mathrm{O}$ production and reduction in both process zones was studied during long-term anaerobic laboratory incubations of aquifer slurries using the ${ }^{15} \mathrm{~N}$ tracer technique. We measured $\mathrm{N}_{2} \mathrm{O}, \mathrm{N}_{2}, \mathrm{NO}_{3}^{-}, \mathrm{NO}_{2}^{-}$, and $\mathrm{SO}_{4}^{2-}$ concentrations as well as parameters of the aquifer material that were related to the relevant electron donors, i.e. organic carbon and pyrite. The laboratory incubations showed a low denitrification activity of heterotrophic denitrification
\end{abstract}

with initial rates between 0.2 and $13 \mu \mathrm{g} \mathrm{N} \mathrm{kg}^{-1} \mathrm{~d}^{-1}$. The process was carbon limited due to the poor availability of its electron donor. In the autotrophic denitrification zone, initial denitrification rates were considerably higher, ranging between 30 and $148 \mu \mathrm{g} \mathrm{Ng}^{-1} \mathrm{~d}^{-1}$, and $\mathrm{NO}_{3}^{-}$as well as $\mathrm{N}_{2} \mathrm{O}$ were completely removed within 60 to 198 days. $\mathrm{N}_{2} \mathrm{O}$ accumulated during heterotrophic and autotrophic denitrification, but maximum concentrations were substantially higher during the autotrophic process. The results revealed a satisfactory transferability of the laboratory incubations to the field scale for autotrophic denitrification, whereas the heterotrophic process less reflected the field conditions due to considerably lower $\mathrm{N}_{2} \mathrm{O}$ accumulation during laboratory incubation. Finally, we applied a conventional model using first-order-kinetics to determine the reaction rate constants $k_{1}$ for $\mathrm{N}_{2} \mathrm{O}$ production and $k_{2}$ for $\mathrm{N}_{2} \mathrm{O}$ reduction, respectively. The goodness of fit to the experimental data was partly limited, indicating that a more sophisticated approach is essential to describe the investigated reaction kinetics satisfactorily. 


\section{Introduction}

The atmospheric concentration of nitrous oxide $\left(\mathrm{N}_{2} \mathrm{O}\right)$, a trace gas contributing to global warming and to the depletion of stratospheric ozone, has increased substantially since preindustrial times and continues to do so (IPCC, 2006). Agricultural ecosystems are considered to be a significant source of $\mathrm{N}_{2} \mathrm{O}$ emissions due to the prevalent application of mineral and organic fertilisers (Mosier et al., 1998). In aquifers of these ecosystems, elevated $\mathrm{N}_{2} \mathrm{O}$ concentrations of up to three orders of magnitude above the concentration in water equilibrated air were found in the near-surface groundwater (Spalding and Parrott, 1994; Well et al., 2005a; von der Heide et al., 2008). Thus, $\mathrm{N}_{2} \mathrm{O}$ in groundwater was assumed to be a potential source contributing to atmospheric $\mathrm{N}_{2} \mathrm{O}$ emissions (Rice and Rogers, 1993; Mosier et al., 1998; Hefting et al., 2003). Despite several recent studies on $\mathrm{N}_{2} \mathrm{O}$ emissions originating from groundwater and agricultural drainage water (Groffman et al., 1998; Heincke and Kaupenjohann, 1999; Hiscock et al., 2003; Reay et al., 2003; Weymann et al., 2008), the significance of these indirect emissions is still uncertain. This could be attributed to two crucial aspects: firstly, $\mathrm{N}_{2} \mathrm{O}$ accumulation in groundwater is complexly controlled. $\mathrm{N}_{2} \mathrm{O}$ is an intermediate product of denitrification, the major process yielding to the occurrence of $\mathrm{N}_{2} \mathrm{O}$ in oxygen depleted groundwater. Thus, $\mathrm{N}_{2} \mathrm{O}$ emissions are a net result of the balance between simultaneously running $\mathrm{N}_{2} \mathrm{O}$ production and reduction to $\mathrm{N}_{2}$. This balance is permanently influenced by different enzyme kinetics of various denitrifying communities according to a number of regulating factors. The complex reaction kinetics may lead to a high variability of $\mathrm{N}_{2} \mathrm{O}$ concentrations in groundwater (von der Heide et al., 2008 ) and to wide ranges of groundwater $\mathrm{N}_{2} \mathrm{O}$ emission factors (Hack and Kaupenjohann, 2002; Weymann et al., 2008). $\mathrm{N}_{2} \mathrm{O}$ in the groundwater can also be produced by nitrification as it was shown by Mühlherr and Hiscock (1998) and Hiscock et al. (2003) for British chalk aquifers. Secondly, it is a challenge to combine research on the reaction kinetics of $\mathrm{N}_{2} \mathrm{O}$ with transport parameters. Clough et al. (2005) stated that the movement and the ultimate fate of $\mathrm{N}_{2} \mathrm{O}$ in subsurface environments are still poorly understood. For example, the consumption of $\mathrm{N}_{2} \mathrm{O}$ in groundwater is poorly investigated (Clough et al., 2007), and depends on the coaction of several factors, mainly the electron donor availability, the $\mathrm{O}_{2}$ concentration, and the $\mathrm{pH}$, respectively. Moreover, the fate of groundwater-derived $\mathrm{N}_{2} \mathrm{O}$ passing the unsaturated zone has not been fully understood (Weymann et al., 2009).

Denitrification has been frequently investigated during laboratory incubation studies using the ${ }^{15} \mathrm{~N}$ tracer or the acetylene blockage technique, mainly to determine the denitrification capacity of soils and aquifer sediments (Smith and Duff, 1988; Ambus and Lowrance, 1991; Paramasivam et al., 1999; Well et al., 2005b). However, laboratory experiments to study the occurrence of $\mathrm{N}_{2} \mathrm{O}$ and its reaction kinetics in groundwater are comparatively rare. Obenhuber and
Lowrance (1991) observed $\mathrm{NO}_{3}^{-}$removal and an accumulation of $\mathrm{N}_{2} \mathrm{O}$ in flow-through microcosms within a period of 302 days, especially in treatments with glucose amendment. Jacinthe et al. (1998) designed a similar experiment with two types of aquifer material over 132 days. The authors reported that heterogeneously distributed "patches" of organic matter induced denitrification in a poorly drained aquifer material, whereas the second type of aquifer material - without these patches - showed no denitrification activity. Furthermore, added dissolved organic carbon (DOC) was obviously not an electron donor for the reduction of $\mathrm{NO}_{3}^{-}$. Blicher-Mathiesen and Hoffmann (1999) conducted an experiment with continuously permeated columns as well as static incubations. In both cases, they observed considerable $\mathrm{NO}_{3}^{-}$removal and net $\mathrm{N}_{2} \mathrm{O}$ production, but they also questioned the transferability of these results to parallel investigated field conditions which did not exhibit $\mathrm{N}_{2} \mathrm{O}$ accumulation due to an efficient reduction of $\mathrm{N}_{2} \mathrm{O}$ to $\mathrm{N}_{2}$. Differences in net $\mathrm{N}_{2} \mathrm{O}$ production between field and laboratory studies were also observed and discussed by Well et al. (2003). By comparing the $\mathrm{N}_{2} \mathrm{O}$ fractions of total denitrification, the laboratory incubation yielded substantially higher values than the field study. Thus, this result confirms the observation of Blicher-Mathiesen and Hoffmann (1999). In contrast, other studies reported a good agreement of laboratory experiments and field methods related to the occurrence of $\mathrm{N}_{2} \mathrm{O}$ (Obenhuber and Lowrance, 1991; Hénault et al., 2001). As becomes clear at this point, it is uncertain whether laboratory investigations of the kinetics of $\mathrm{N}_{2} \mathrm{O}$ production and reduction are applicable to field conditions.

Recently, the magnitude and controls of indirect $\mathrm{N}_{2} \mathrm{O}$ fluxes from the groundwater have been investigated by combining field monitoring, process studies and modelling. Research activities were conducted within the unconsolidated sandy Fuhrberger Feld aquifer (FFA) in northern Germany. The FFA has been a subject of extensive research activities since the 1980s (reviewed in Korom, 1992), since the catchment is in an area of conflict between drinking water supply on the one hand and agricultural activities causing considerable inputs of pollutants via seepage, especially of nitrate, on the other hand (Kölle et al., 1985; Frind et al., 1990). In the FFA, substantial microbially mediated processes and reactions like denitrification and desulfurication (heterotrophic reduction of sulfate, Korom, 1991, 1992; Böttcher et al., 1991) occur, strongly influencing groundwater geochemistry. Autotrophic denitrification with pyrite as an electron donor was identified as the dominant microbial reaction for $\mathrm{NO}_{3}^{-}$ elimination (Kölle et al., 1985) in depths beyond 2-3 m below the groundwater table (Böttcher et al., 1992). This part of the aquifer is denoted as "autotrophic denitrification zone" later on in this paper. The process of autotrophic denitrification was stoichiometricly described by Kölle et al. (1985) and Böttcher et al. (1990) as a reaction mediated by the bacteria Thiobacillus denitrificans: 
$5 \mathrm{FeS}_{2}+14 \mathrm{NO}_{3}^{-}+4 \mathrm{H}^{+} \rightarrow 7 \mathrm{~N}_{2}+10 \mathrm{SO}_{4}^{2-}$

$+5 \mathrm{Fe}^{2+}+2 \mathrm{H}_{2} \mathrm{O}$

Kölle et al. (1985) conducted an incubation experiment in order to evaluate the sulfate formation capacity of nitrate amended aquifer slurries from different depths. They found an ongoing sulfate formation during a 284-days-period and calculated the potential of autotrophic denitrification on the basis of pyrite oxidation.

In the case of the near-surface groundwater, von der Heide et al. (2008) confirmed former assumptions that heterotrophic denitrification with organic carbon as an electron donor replaced autotrophic denitrification due to an exhaustion of pyrite (Kölle et al., 1983; Böttcher et al., 1991):

$$
5 \mathrm{CH}_{2} \mathrm{O}+4 \mathrm{NO}_{3}^{-} \rightarrow 2 \mathrm{~N}_{2}+4 \mathrm{HCO}_{3}^{-}+\mathrm{CO}_{2}+3 \mathrm{H}_{2} \mathrm{O}
$$

Autotrophic denitrification is much more efficient for $\mathrm{NO}_{3}^{-}$ reduction than heterotrophic denitrification in the nearsurface groundwater. With respect to denitrification efficiency, Weymann et al. (2008) revealed the considerable difference between heterotrophic and autotrophic denitrification by determination of "excess nitrogen" in groundwater samples. Hence, high $\mathrm{NO}_{3}^{-}$concentrations are limited to the top few metres of the aquifer, but the rest of the aquifer is almost $\mathrm{NO}_{3}^{-}$-free (Frind et al., 1990; von der Heide et al., 2009).

The recent research activities in the FFA focused on the dynamics of $\mathrm{N}_{2} \mathrm{O}$ in the system groundwater - unsaturated zone. Deurer et al. (2008) investigated the accumulation and dynamics of $\mathrm{N}_{2} \mathrm{O}$ near the groundwater table and its transfer into the unsaturated zone from an exchange zone extending $0.55 \pm 0.22 \mathrm{~m}$ below the groundwater table. They reported that the groundwater may also act as a sink for $\mathrm{N}_{2} \mathrm{O}$. An extremely high spatial variability of $\mathrm{N}_{2} \mathrm{O}$ concentrations in the near-surface groundwater of the FFA was postulated by von der Heide et al. (2008). The authors identified the land use and the distance of the groundwater level to the soil surface as factors governing the magnitude of $\mathrm{N}_{2} \mathrm{O}$ concentrations in the near-surface groundwater. Weymann et al. (2008) determined groundwater $\mathrm{N}_{2} \mathrm{O}$ emission factors with respect to initial $\mathrm{NO}_{3}^{-}$concentrations and assessed these factors related to $\mathrm{N}_{2} \mathrm{O}$ accumulation during different stages of the denitrification progress.

In the present study, we investigated the kinetics of $\mathrm{N}_{2} \mathrm{O}$ production and reduction in aquifer material from the FFA. The specific objectives of this study are (i) to determine the time courses of $\mathrm{NO}_{3}^{-}, \mathrm{N}_{2} \mathrm{O}$ and $\mathrm{N}_{2}$ during long-term laboratory incubation of aquifer material samples, (ii) to evaluate kinetic rate constants of $\mathrm{N}_{2} \mathrm{O}$ production and reduction during heterotrophic and autotrophic denitrification using a conventional $k_{1}-k_{2}$-model that follows first-order-kinetics and (iii) to assess the validity of the laboratory experiments for the relevant in situ processes.

\section{Materials and methods}

\subsection{Study site}

The Fuhrberger Feld aquifer (FFA) in northern Germany is located about $30 \mathrm{~km}$ northeast of the city of Hannover. The unconfined aquifer consists of pleistocene, highly permeable carbonate-free sands and gravels with a thickness of 20-40 m underlain by impermeable cretaceous clays. More information about the soils, the hydrology and the land use of the research site is given by Frind et al. (1990), Deurer et al. (2008) and von der Heide et al. (2008). All recent studies were conducted within a groundwater flowpath strip equipped with multilevel sampling wells (Deurer et al., 2008). In this study, we investigated the groundwater and the aquifer material at the multilevel sampling wells B1 and I1 (see von der Heide et al., 2009). Since the aquifer consists of vertically separated denitrification zones according to the availibility of electron donors, i.e. organic carbon and pyrite (von der Heide et al., 2008), we were able to investigate not only the kinetics of $\mathrm{N}_{2} \mathrm{O}$ production and reduction during heterotrophic denitrification, but also during the autotrophic pathway. The main characteristics of the aquifer material are shown in Table 1.

\subsection{Sampling procedures}

Groundwater was collected from the multilevel sampling wells (Böttcher et al., 1985) in order to measure the denitrification related parameters $\mathrm{N}_{2} \mathrm{O}, \mathrm{NO}_{3}^{-}, \mathrm{SO}_{4}^{2-}, \mathrm{O}_{2}$, DOC, and $\mathrm{pH}$. The groundwater samples were collected in September 2005, December 2005 and March 2006 from the multilevel sampling well B1 using a peristaltic pump (Masterflex, COLE-PARMER, Vernon Hills, USA) as described in detail by Weymann et al. (2008). At the multilevel sampling well I1, a single sampling campaign was conducted in March 2006. Here, we collected the groundwater with a plastic syringe, applying the method introduced by Deurer et al. (2008). At both wells, the depth resolution was $0.2 \mathrm{~m}$ in the near-surface groundwater $(0.1 \mathrm{~m}-2.1 \mathrm{~m}$ below the groundwater table) and $1.0 \mathrm{~m}$ in the subjacent groundwater down to a depth of $10 \mathrm{~m}$ below the soil surface.

Aquifer material was collected at the well B1 and at the plot appendant to well I1 for laboratory incubations to derive the parameters of the $\mathrm{N}_{2} \mathrm{O}$ reaction kinetics. This was done using a hand-operated bailer boring auger set (EIJKELKAMP, Giesbeek, The Netherlands) consisting of a stainless steel bailer, casing tubes (OD of $10 \mathrm{~cm}$ ) and a tube clamp. At the multilevel sampling well B1, we collected aquifer material in October 2005 from three depth intervals in the zone of heterotrophic denitrification: $2.0-2.6 \mathrm{~m}, 2.6-$ $3.0 \mathrm{~m}$ and $3.4-4.0 \mathrm{~m}$ below the soil surface. At the plot of the multilevel sampling well I1, the aquifer material was sampled at three spots that were spatially arranged as described by von der Heide et al. (2008). Sampling took place in October 2005 from the depth intervals $1.5 \mathrm{~m}-2.0 \mathrm{~m}, 2.0 \mathrm{~m}-2.5 \mathrm{~m}$ 
Table 1. Location and basic properties of the investigated aquifer materials.

\begin{tabular}{|c|c|c|c|c|c|c|c|c|c|}
\hline \multirow[t]{2}{*}{ Sample location } & \multirow{2}{*}{$\begin{array}{l}\text { Depth interval } \\
\quad[\mathrm{m}]\end{array}$} & \multirow{2}{*}{$\begin{array}{l}\text { Dentrification } \\
\text { zone }\end{array}$} & Organic $\mathrm{C}$ & Total N & \multirow[t]{2}{*}{ C-to-N ratio } & $\mathrm{DOC}^{1}$ & $C_{\mathrm{hws}}^{2}$ & Toal S & \multirow{2}{*}{$\begin{array}{l}\text { Clay } \\
{[\%]}\end{array}$} \\
\hline & & & \multicolumn{2}{|c|}{$\left[\mathrm{mg} \mathrm{kg}^{-1}\right]$} & & \multicolumn{3}{|c|}{$\left[\mathrm{mg} \mathrm{kg}^{-1}\right]$} & \\
\hline B1 & $2.0-2.6$ & "heterotrophic" & 539.62 & 17.22 & 31.34 & 28.13 & n.d. ${ }^{3}$ & 47.35 & 0.00 \\
\hline B1 & $2.6-3.0$ & & 587.66 & 40.94 & 14.35 & 16.37 & n.d. ${ }^{3}$ & 45.79 & 0.00 \\
\hline B1 & $3.4-4.0$ & & 658.61 & 39.46 & 16.69 & 13.27 & n.d. ${ }^{3}$ & 39.65 & 0.00 \\
\hline I1-S1 & $1.5-2.0$ & & 816.12 & 53.43 & 15.27 & 19.27 & 167.25 & 44.61 & 0.00 \\
\hline I1-S1 & $2.0-2.5$ & & 609.26 & 40.22 & 15.15 & 16.28 & 111.80 & 75.78 & 0.00 \\
\hline I1-S1 & $2.5-3.0$ & & 485.18 & 67.82 & 7.15 & 12.69 & 109.66 & 91.55 & 0.00 \\
\hline I1-S2 & $1.5-2.0$ & & 536.64 & 23.78 & 22.57 & 16.40 & 91.59 & 24.76 & 0.00 \\
\hline I1-S2 & $2.0-2.5$ & & 506.05 & 32.39 & 15.62 & 17.82 & 101.66 & 13.57 & 0.00 \\
\hline I1-S3 & $1.5-2.0$ & & 729.46 & 42.06 & 17.34 & 21.09 & 113.56 & 33.72 & 0.00 \\
\hline I1-S3 & $2.0-2.5$ & & 584.57 & 36.82 & 15.88 & 17.73 & 103.55 & 41.67 & 0.00 \\
\hline I1-S3 & $2.5-3.0$ & & 527.99 & 41.40 & 12.75 & 13.45 & 94.90 & 64.33 & 0.00 \\
\hline I1-1 & $6.5-7.0$ & "autotrophic" & 556.00 & 30.00 & 18.53 & 8.77 & 330.20 & 302.45 & 0.70 \\
\hline I1-2 & $6.5-7.0$ & & 437.95 & 129.84 & 3.37 & 7.65 & 338.39 & 265.47 & 0.95 \\
\hline I1-3 & $6.5-7.0$ & & 469.38 & 52.62 & 8.92 & 6.85 & 351.00 & 457.96 & 1.99 \\
\hline I1-4 & $6.5-7.0$ & & 714.68 & 65.07 & 10.98 & 9.88 & 390.00 & 430.86 & 2.22 \\
\hline I1-5 & $6.5-7.0$ & & 1293.73 & 94.97 & 13.62 & 8.46 & 258.70 & 379.89 & 3.44 \\
\hline I1-6 & $6.5-7.0$ & & 1488.87 & 123.58 & 12.05 & 11.87 & 267.15 & 396.13 & 5.09 \\
\hline I1-7 & $6.5-7.0$ & & 685.32 & 39.72 & 17.25 & 10.37 & 284.05 & 253.24 & 1.95 \\
\hline I1-8 & $6.5-7.0$ & & 461.45 & 45.33 & 10.18 & 8.27 & 247.00 & 361.88 & 1.50 \\
\hline I1-9 & $6.5-7.0$ & & 894.72 & 70.58 & 12.68 & 12.27 & 253.50 & 376.33 & 3.55 \\
\hline I1-10 & $6.5-7.0$ & & 545.91 & 41.64 & 13.11 & 7.25 & 318.50 & 436.03 & 2.26 \\
\hline I1-11 & $6.5-7.0$ & & 720.72 & 55.23 & 13.05 & 7.00 & 278.20 & 361.84 & 3.11 \\
\hline
\end{tabular}

${ }^{1}$ Extractable dissolved organic carbon; ${ }^{2}$ Extractable hot-water soluble carbon; ${ }^{3}$ n.d.: not determined

and $2.5 \mathrm{~m}-3.0 \mathrm{~m}$ below the soil surface (heterotrophic denitrification zone). To sample the autotrophic zone, a PVC pipe (OD of $100 \mathrm{~mm}$ ) was installed at $6.5 \mathrm{~m}$ depth at one spot very close to the well using a drilling rig (WELLCO-DRILL, WD 500, Beedenbostel, Germany) with a hollow-stem auger (OD of $205 \mathrm{~mm}$, ID of $106 \mathrm{~mm}$ ). Samples were collected using the bailer. During sampling, the bottom part of the PVC pipe was continuously refilled with surrounding aquifer material and reduced groundwater from the same depth, i.e. sampling included replacing of the original sediment with sediment in the vicinity of the borehole. Thus, sediment with different properties from slightly different areas was sampled. Hence, we were able to collect samples differing in texture and chemical composition from a single spot. The sampling of the autotrophic zone was conducted in December 2005.

The collected aquifer material was transferred from the bailer to $16 \mathrm{~L}$ plastic buckets. We filled the buckets until the supernatant groundwater overflowed. Subsequently, the buckets were closed airtight with a lid. From the heterotrophic denitrification zone, we filled one bucket per depth interval. From the autotrophic denitrification zone, 11 buckets were collected from the same depth interval. The aquifer material was stored at groundwater temperature $\left(10^{\circ} \mathrm{C}\right)$ and batched for laboratory incubations within four weeks.

\subsection{Laboratory incubations}

We performed a laboratory method using the ${ }^{15} \mathrm{~N}$ tracer technique that reaches back to the seminal study of Nõmmik (1956) who quantified the gaseous denitrification products from soils receiving $\mathrm{K}^{15} \mathrm{NO}_{3}$ by mass spectrometry. The approach of anaerobic incubation of $\mathrm{NO}_{3}^{-}$amended slurries has been extensively used for measuring denitrification and $\mathrm{N}_{2} \mathrm{O}$ production (Tiedje, 1994; Hénault et al., 2001; Well et al., 2003, 2005a). In detail, $500 \mathrm{~g}$ of each aquifer material were transferred as slurries in 4 replications to $1125-\mathrm{mL}$ transfusion bottles and amended with $400 \mathrm{~mL}$ of a $\mathrm{K}^{15} \mathrm{NO}_{3}$ test solution $\left(10 \mathrm{mg} \mathrm{N} \mathrm{L}^{-1} ; 60\right.$ atom $\left.\%{ }^{15} \mathrm{~N}\right)$. The transfusion bottles were sealed with rubber septa and aluminium screw caps. The gravimetric water content of the slurries was $0.19 \mathrm{~g} \mathrm{~g}^{-1}$, resulting in a dry weight of $405 \mathrm{~g}$. The volume of the solid matter was $153 \mathrm{~mL}$, assuming a particle density of $2.65 \mathrm{~g} \mathrm{~cm}^{-3}$. Taking the water content of the slurries into account, we determined the liquid volume in the bottles as $495 \mathrm{~mL}$. Consequently, the headspace volume was $477 \mathrm{~mL}$. We established anaerobic conditions by three cycles of evacuation and refilling with $\mathrm{N}_{2}$, respectively. The duration of each cycle was about 10 minutes. This method was examined carefully prior to the incubation experiment. We also checked the headspace $\mathrm{O}_{2}$ concentration 
(see Sect. 2.4) to ensure that $\mathrm{O}_{2}$ was sufficiently removed. Subsequently, the samples were incubated at $10^{\circ} \mathrm{C}$, which is the approximate groundwater temperature as estimated from the mean annual air temperature. Gas and water samples were collected following a flexible sampling schedule according to the progress of denitrification. Prior to each sampling, the liquid and the gas phase were equilibrated by vigorous shaking for $3 \mathrm{~h}$. $24 \mathrm{~mL}$ of the headspace gas were sampled using a double syringe system consisting of two 30-mL plastic syringes equipped with 3-way Luer-lock stop cocks (BRAUN, Melsungen, Germany) which were connected to each other. After mixing the gas sample within the syringe system, $12 \mathrm{~mL}$ from each of the separate syringes were transferred into fully evacuated Exetainers ${ }^{\mathrm{TM}}$ (LABCO, High Wycombe, UK). One Exetainer ${ }^{\mathrm{TM}}$ was stored for the measurement of $\mathrm{N}_{2} \mathrm{O}$ by gas chromatography, the other for the ${ }^{15}\left(\mathrm{~N}_{2} \mathrm{O}+\mathrm{N}_{2}\right)$ analysis by mass spectrometry and both were analysed within 3 weeks. To retain normal pressure in the serum bottles, we re-injected an equivalent volume of pure $\mathrm{N}_{2}$ after sampling. The resulting dilution of the headspace gas was taken into account in the calculation of the ${ }^{15}\left(\mathrm{~N}_{2} \mathrm{O}+\mathrm{N}_{2}\right)$ concentrations. Water samples were collected with a syringe. Routinely, we withdrew a $15 \mathrm{~mL}$ aliquot for $\mathrm{NO}_{3}^{-}$analysis. Subsequently, an equivalent amout of the oxygen-free $\mathrm{K}^{15} \mathrm{NO}_{3}$ test solution was re-injected. The $\mathrm{NO}_{3}^{-}$concentration of the test solution was adjusted according to the expected sample $\mathrm{NO}_{3}^{-}$concentration. The oxygenfree $\mathrm{K}^{15} \mathrm{NO}_{3}$ test solution was manufactured in a $10 \mathrm{~L}$ glas tank sealed with a butyl rubber stopper. To establish anoxic conditions, the solution was flushed with $\mathrm{N}_{2}$ for $1 \mathrm{~h}$ using a stainless steel capillary tube and was stirred simultaneously by magnetic stirring. Subsequently, $\mathrm{O}_{2}$ in the headspace of the tank was examined by GC measurement as described in Sect. 2.4.

\subsection{Analytical techniques}

The aquifer materials' particle size distribution was determined gravimetrically after separating the fractions by sieving and sedimentation following the Atterberg-method (Schlichting et al., 1995). Total organic carbon $\left(C_{\text {org }}\right)$ and total $\mathrm{N}$ of the pulverised and carbonate-free aquifer material was measured using the elemental analyser vario MAX CN (ELEMENTAR ANALYSENSYSTEME, Hanau, Germany) equipped with a thermal conductivity detector. The precision of the analysis was $0.5 \%$. Total sulfur of the identical samples was analysed with a vario EL III elemental analyser (ELEMENTAR ANALYSENSYSTEME, Hanau, Germany) equipped with a thermal conductivity detector and an UVabsorption photometer. The precision of the analysis was $0.1 \%$.

$\mathrm{NO}_{3}^{-}$and $\mathrm{NO}_{2}^{-}$in the water samples from the laboratory incubations were analysed photometricly using a continuous flow analyser (Skalar, Erkelenz, Germany). The measurement precision was $5 \%$. The $\mathrm{pH}$ of these samples was measured with a pH-meter (METROHM 632, Filderstadt, Germany). DOC in the water samples from the laboratory incubations, in cold-water extracts, and hot-water soluble organic carbon $\left(C_{\mathrm{hws}}\right)$ were analysed as described by Well et al. (2005b). $\mathrm{SO}_{4}^{2-}$ concentrations of the water samples from the laboratory incubations (autotrophic denitrification zone) were determined by potentiometric back-titration using EDTA as a titrant. Prior to back-titration, $\mathrm{SO}_{4}^{2-}$ was precipitated as barium sulfate after addition of barium chloride solution in excess. Please note that it was not possible to measure $\mathrm{SO}_{4}^{2-}$ also in the water samples of the laboratory incubations from the heterotrophic denitrification zone, because the sample volumes after measuring $\mathrm{NO}_{3}^{-}$and $\mathrm{NO}_{2}^{-}$ were limited and an analysis based on back titration was not possible because of the comparatively low sulfate concentrations.

$\mathrm{NO}_{3}^{-}, \mathrm{SO}_{4}^{2-}$, and potassium concentrations in the groundwater samples collected from the multilevel sampling wells were determined by ion chromatography (ICS-90, DIONEX, Idstein, Germany) with a precision of $5 \%$. DOC, $\mathrm{pH}$ and the $\mathrm{O}_{2}$ concentration of the groundwater were measured on site as specified by Deurer et al. (2008).

$\mathrm{N}_{2} \mathrm{O}$ was measured using a gas chromatograph equipped with an electron capture detector and an auto sampler that was described earlier (Well et al., 2003). The ${ }^{15} \mathrm{~N}$ analysis of $\left(\mathrm{N}_{2} \mathrm{O}+\mathrm{N}_{2}\right)$ in the headspace gas was conducted following the method specified in Well et al. $(1998,2003)$. The gas concentrations of the sample solutions (dissolved $\mathrm{N}_{2} \mathrm{O}$ and $\mathrm{N}_{2}$ ) were calculated according to Henry's laws from the headspace concentrations using the Bunsen absorption coefficients of $\mathrm{N}_{2} \mathrm{O}$ and $\mathrm{N}_{2}$, respectively (Weiss, 1970; Weiss and Price, 1980). The calculation was described in detail by Well and Myrold (1999) and Well et al. (2003). $\mathrm{O}_{2}$ was monitored throughout the laboratory incubations to ensure anaerobic conditions. We used a gas chromatograph (Fractovap 400, CARLO ERBA, Milano) equipped with a thermal conductivity detector and a packed column ( $1.8 \mathrm{~m}$ length, $4 \mathrm{~mm}$ ID, molecular sieve $5 \AA$ ). Helium functioned as the carrier gas.

\subsection{Reaction kinetics}

First-order kinetics is frequently used to model processes in the field of groundwater biogeochemistry. For example, Böttcher et al. (1989) applied this kinetics to estimate field denitrification rates in the FFA. In the case of our laboratory approach, we consider a two-step reaction chain for $\mathrm{N}_{2} \mathrm{O}$ production and $\mathrm{N}_{2} \mathrm{O}$ reduction (Holtan-Hartwig et al., 2002) in order to characterise the heterotrophic and autotrophic denitrification process:

$\mathrm{NO}_{3}^{-} \stackrel{k 1}{\longrightarrow} 1 / 2 \mathrm{~N}_{2} \mathrm{O} \stackrel{k 2}{\longrightarrow} 1 / 2 \mathrm{~N}_{2}$

It is important to anticipate that concentrations of nitrite $\left(\mathrm{NO}_{2}^{-}\right)$were below detection limit during the laboratory incubations, i.e. no reaction limited step between $\mathrm{NO}_{3}^{-}$and $\mathrm{N}_{2} \mathrm{O}\left(k_{1}\right)$ occurred. For further discussion see Sect. 4.2. 
Hoehener et al. (2003) presented an analytical solution following first-order kinetics. This $k_{1}-k_{2}$-standard model is described by the following differential equations for $\mathrm{NO}_{3}^{-}$and $\mathrm{N}_{2} \mathrm{O}$, respectively:

$\frac{d C_{\mathrm{NO} 3}}{d t}=-k_{1} \cdot C_{\mathrm{NO} 3}$,

$\frac{d C_{\mathrm{N} 2 \mathrm{O}}}{d t}=F \cdot k_{1} \cdot C_{\mathrm{NO} 3}-k_{2} \cdot C_{\mathrm{N} 2 \mathrm{O}}$

The analytical solutions are:

$C_{\mathrm{NO} 3}(t)=C_{0} \cdot \exp \left(-k_{1} \cdot t\right)$

$\left(k_{1} \neq k_{2}\right): \quad C_{\mathrm{N} 2 \mathrm{O}}(t)=F \cdot C_{0} \cdot \frac{k_{1}}{\left(k_{2}-k_{1}\right)}$.

$\left[\exp \left(-k_{1} \cdot t\right)-\exp \left(-k_{2} \cdot t\right)\right]$

$\left(k_{1}=k_{2}\right): \quad C_{\mathrm{N} 2 \mathrm{O}}(t)=F \cdot C_{0} \cdot k_{1} \cdot t \cdot \exp \left(-k_{1} \cdot t\right)$,

where $F$ is the stoichiometric factor and $C_{0}$ is the initial nitrate concentration. We note that the sum of $\mathrm{N}_{2}$ and $\mathrm{N}_{2} \mathrm{O}$ is only a function of $k_{1}$ and the analytical solution follows by mass balance considerations:

$C_{\mathrm{sum}}(t)=\mathrm{C}_{\mathrm{N} 2}(t)+C_{\mathrm{N} 2 \mathrm{O}}(t)=F \cdot\left(C_{0}-C_{\mathrm{NO} 3}(t)\right)$.

A Marquardt-Levenberg fit was conducted to all heterotrophic and autotrophic data sets, where the analytical solutions are used as fitting function. All calculations were carried out with the mathematical software Mathematica 6.0. For each data set three different fits were conducted: (i) a 1step 3-parameter fit, (ii) a sequential (or 2-step) 3-parameter fit, and (iii) a sequential 2-parameter fit. The fitting parameters for the 3-parameter fits were $C_{0}, k_{1}$ and $k_{2}$, respectively.

To further evaluate the control of $\mathrm{NO}_{3}^{-}$reduction by denitrification we also used a simpler approach which did not include the distinction between $\mathrm{N}_{2} \mathrm{O}$ production and reduction and was based on zero-order-kinetics. Reaction rates $(D)$ were derived from the slope of $\left(\mathrm{N}_{2} \mathrm{O}+\mathrm{N}_{2}\right)$ over time in order to correlate denitrification with the independent parameters of the aquifer material. Initial values of $D\left(D_{i}\right)$ were obtained from the first 7 days of incubation. Maximum values of $D\left(D_{\max }\right)$ were calculated from the maximum slopes of the $\left(\mathrm{N}_{2} \mathrm{O}+\mathrm{N}_{2}\right)$-curve. Finally, we used the maximum $\mathrm{N}_{2} \mathrm{O}$ concentration during incubation $\left(c \mathrm{~N}_{2} \mathrm{O}_{\max }\right)$ and the ratio between $\mathrm{N}_{2} \mathrm{O}$ and $\left(\mathrm{N}_{2} \mathrm{O}+\mathrm{N}_{2}\right)$ at maximum $\mathrm{N}_{2} \mathrm{O}$ concentration $\left(c \mathrm{~N}_{2} \mathrm{O}_{\text {max }}\right.$-to- $\left.\left[\mathrm{N}_{2} \mathrm{O}+\mathrm{N}_{2}\right]\right)$ as qualitative indicators for the balance between production and reduction of $\mathrm{N}_{2} \mathrm{O}$.

Since we expected $\mathrm{SO}_{4}^{2-}$ production in the samples from the autotrophic denitrification zone (Kölle et al., 1985), $\mathrm{SO}_{4}^{2-}$ production rates were obtained from the increase of $\mathrm{SO}_{4}^{2-}$ concentrations. The rates were calculated using the difference between the final and the initial $\mathrm{SO}_{4}^{2-}$ concentration depending on time and were converted to $\mathrm{N}$ equivalents according to Eq. (1) in order to facilitate a comparison with the denitrification rates.

\section{Results}

\subsection{Multilevel well measurements}

At the investigated wells, each of the vertical concentration gradients of $\mathrm{NO}_{3}^{-}$and $\mathrm{N}_{2} \mathrm{O}$ showed a similar pattern. In the near-surface groundwater, $\mathrm{NO}_{3}^{-}$concentrations initially increased downwards in both profiles to a mean value of $34 \mathrm{mg} \mathrm{NL}^{-1}$ in a depth of $3.8 \mathrm{~m}$ below the soil surface at B1 and to $30 \mathrm{mg} \mathrm{N} \mathrm{L}^{-1}$ in a depth of $3.2 \mathrm{~m}$ below the soil surface at I1, respectively (Fig. 1a). Below $4 \mathrm{~m}$, where the autotrophic denitrification mainly governs $\mathrm{NO}_{3}^{-}$reduction, $\mathrm{NO}_{3}^{-}$concentrations decreased rapidly and reached zero in a depth of $7 \mathrm{~m}$ at both wells. In the case of $\mathrm{N}_{2} \mathrm{O}$ (Fig. 1b), we identified two layers where the concentrations were highest: first, there is a zone of $\mathrm{N}_{2} \mathrm{O}$ accumulation in the uppermost groundwater coinciding with an "exchange zone" that was recently reported by Deurer et al. (2008). We observed $\mathrm{N}_{2} \mathrm{O}$ concentrations up to $1.84 \mathrm{mg} \mathrm{N} \mathrm{L}^{-1}$ in a depth of $2.0 \mathrm{~m}$ below the soil surface at B1 and $1.63 \mathrm{mg} \mathrm{NL}^{-1}$ in a depth of $1.6 \mathrm{~m}$ below the soil surface $(0.54 \mathrm{~m}$ below the groundwater table) at I1. Second, Fig. 1b shows a sharp concentration peak in both profiles, consisting of an outstanding value in $5 \mathrm{~m}$ and $6 \mathrm{~m}$ depth, respectively. Between these layers, $\mathrm{N}_{2} \mathrm{O}$ concentrations in the groundwater were substantially lower at both wells, but still up to three orders of magnitude higher than the $\mathrm{N}_{2} \mathrm{O}$ concentration in water equilibrated air. In the autotrophic denitrification zone, $\mathrm{N}_{2} \mathrm{O}$ concentrations declined rapidly after the sharp peak and were below detection limit in $6 \mathrm{~m}$ at $\mathrm{B} 1$ and $7 \mathrm{~m}$ at $\mathrm{I} 1$, respectively. In contrast to the vertical concentration gradients of $\mathrm{NO}_{3}^{-}$and $\mathrm{N}_{2} \mathrm{O}$, the $\mathrm{SO}_{4}^{2-}$ concentration pattern was different at the investigated wells (Fig. 1c). At I1, we observed an abrupt increase from $67 \mathrm{mg} \mathrm{L}^{-1}$ in a depth of $5 \mathrm{~m}$ to $113 \mathrm{mg} \mathrm{L}^{-1}$ in a depth of $6 \mathrm{~m}$ coinciding with the concentration peak of $\mathrm{N}_{2} \mathrm{O}$. Furthermore, the $\mathrm{SO}_{4}^{2-}$ concentrations remained elevated in the deeper groundwater compared to the near-surface groundwater. At B1, these phenomena did not occur during all sampling campaigns (further details will be given in the discussion section).

Ranges of groundwater $\mathrm{pH}$ in the profiles indicated acidic conditions and were similar at the investigated wells. The $\mathrm{pH}$ ranged between 4.1 and 6.0 at $\mathrm{B} 1$ and between 4.9 and 5.7 at I1, respectively (Fig. 1f). $\mathrm{O}_{2}$ concentrations were highest in the near-surface groundwater. Values up to $3.0 \mathrm{mg} \mathrm{L}^{-1}$ (B1) and $4.2 \mathrm{mg} \mathrm{L}^{-1}$ (I1) suggested oxic conditions (Fig. 1e). In contrast, practically anoxic conditions dominated in the groundwater of the autotrophic denitrification zone.

\subsection{Laboratory incubation: reaction rates, time courses of the $\mathrm{N}$-species, $\mathrm{pH}$, and correlation analysis}

The concentration courses of $\mathrm{N}_{2} \mathrm{O}$, of the total denitrification products $\left(\mathrm{N}_{2} \mathrm{O}+\mathrm{N}_{2}\right)$, and of $\mathrm{NO}_{3}^{-}$are represented in Figs. 2 and 3, respectively. Whereas Fig. 2 refers to heterotrophic 


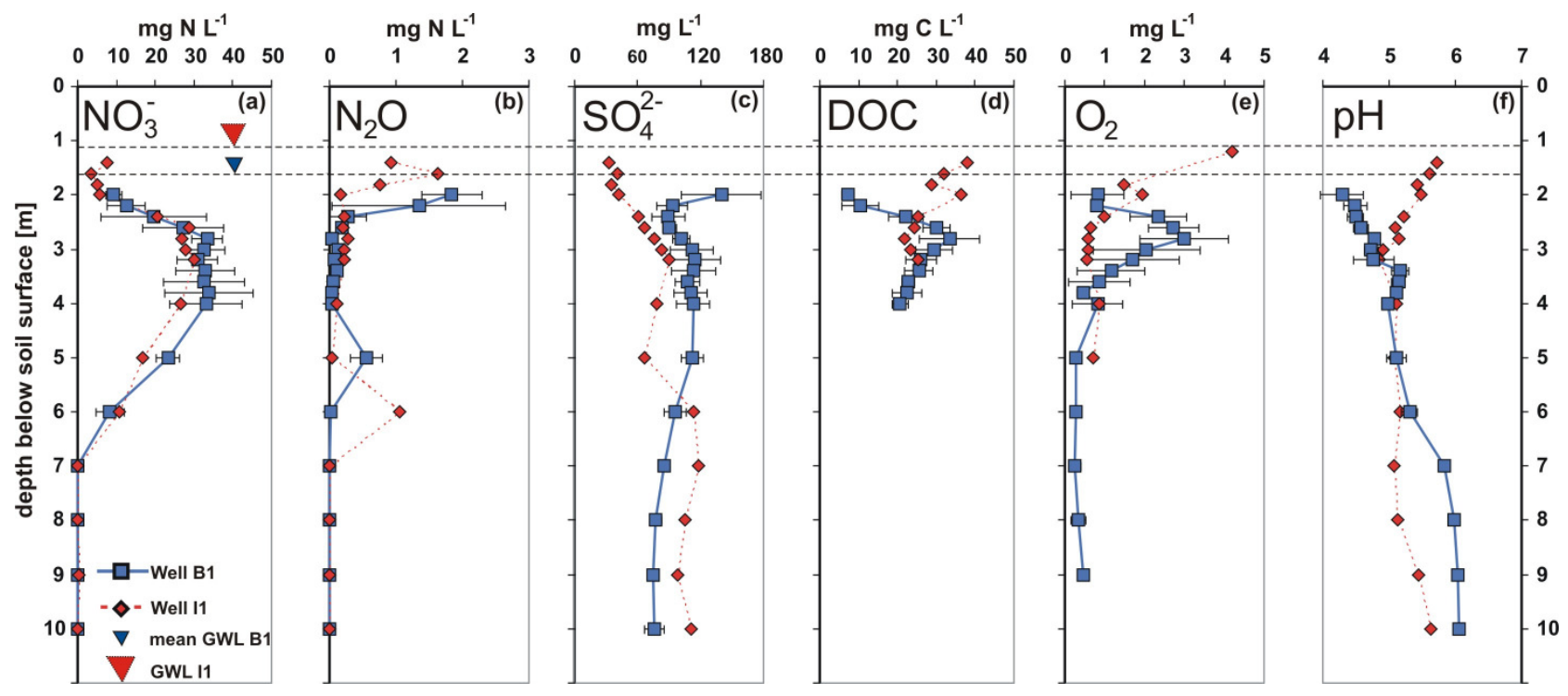

Fig. 1. Vertical gradients of $\mathrm{NO}_{3}^{-}-, \mathrm{N}_{2} \mathrm{O}-, \mathrm{SO}_{4}^{2-}-$, DOC-, and $\mathrm{O}_{2}$ concentrations as well as $\mathrm{pH}$ at the wells $\mathrm{B} 1$ and $\mathrm{I} 1$. The data of well $\mathrm{B} 1$ are mean values of three sampling campaigns, the error bars denote the standard deviation (only shown when larger than the symbols). The dotted lines indicate the groundwater level at I1 (GWL I1) and the mean groundwater level of the three sampling campaigns conducted at B1 (GWL B1), respectively.

denitrification in the near-surface groundwater, Fig. 3 shows the results for the autotrophic denitrification zone. $\mathrm{N}_{2} \mathrm{O}$ and $\left(\mathrm{N}_{2} \mathrm{O}+\mathrm{N}_{2}\right)$ were detectable in all samples indicating the general occurrence of denitrification. In contrast, $\mathrm{NO}_{2}^{-}$concentrations were found to be below detection limit in all samples throughout the entire incubations of the aquifer slurries. There were substantial differences in denitrification activity and the kinetics of $\mathrm{N}_{2} \mathrm{O}$ production and reduction between heterotrophic and autotrophic denitrification, and also within these two groups. Calculated rates of autotrophic denitrification $\left(D_{i}, D_{\max }\right.$, Table 2$)$, symbolized by the slopes of the $\left(\mathrm{N}_{2} \mathrm{O}+\mathrm{N}_{2}\right)$ curves (Fig. 3), were typically one order of magnitude higher than the rates of heterotrophic denitrification. The coincidence of $\mathrm{NO}_{3}^{-}$reduction and $\left(\mathrm{N}_{2} \mathrm{O}+\mathrm{N}_{2}\right)$ production indicate that the mass balance was satisfactory (Figs. 2 and 3). Consequently, $\mathrm{NO}_{3}^{-}$concentrations decreased continuously until complete elimination of $\mathrm{NO}_{3}^{-}$during autotrophic denitrification (Fig. 3), whereas the decrease of $\mathrm{NO}_{3}^{-}$concentrations during heterotrophic denitrification was marginal and the residual $\mathrm{NO}_{3}^{-}$pool was much greater than the reduced one (Fig. 2).

The balance of $\mathrm{N}_{2} \mathrm{O}$ production and reduction yielded a characteristic course of the $\mathrm{N}_{2} \mathrm{O}$ concentration curve as it was reported by Holtan-Hartwig et al. (2000) and Well et al. (2005a): the majority of samples showed an increase to a maximum concentration $\left(c \mathrm{~N}_{2} \mathrm{O}_{\max }\right)$ followed by a decrease that resulted in complete $\mathrm{N}_{2} \mathrm{O}$ reduction for the case of autotrophic denitrification. However, the $\mathrm{N}_{2} \mathrm{O}$ concentration courses and $c \mathrm{~N}_{2} \mathrm{O}_{\max }$ values were highly variable and the standard deviations partially indicate corresponding uncertainties.
In the heterotrophic denitrification zone, our sampling method enabled collection and laboratory incubation of slurries from different depth intervals (Table 1). The time courses of $\mathrm{N}_{2} \mathrm{O}$ showed an increase of $c \mathrm{~N}_{2} \mathrm{O}_{\max }$ with depth (Fig. 2, Table 2). Consequently, $c \mathrm{~N}_{2} \mathrm{O}_{\max }$ was highest in 2.5$3.0 \mathrm{~m}$ at $\mathrm{I} 1-\mathrm{S} 1$, in $2.5-3.0 \mathrm{~m}$ at $\mathrm{I} 1-\mathrm{S} 3$ and in $3.4-4.0 \mathrm{~m}$ at B1 with 79,79 and $59 \mu \mathrm{g} \mathrm{N}_{2} \mathrm{O}-\mathrm{N} \mathrm{kg}^{-1}$, respectively. In contrast, $c \mathrm{~N}_{2} \mathrm{O}_{\text {max }}$ was lowest in the topmost depth intervals where it ranged between 2.4 and $23 \mu \mathrm{g} \mathrm{N}_{2} \mathrm{O}-\mathrm{N} \mathrm{kg}^{-1}$. The results showed that $\mathrm{N}_{2} \mathrm{O}$ concentrations were close to the $c \mathrm{~N}_{2} \mathrm{O}_{\max }$ values for a period $>100$ days in the majority of cases and decreased slowly towards the end of the incubation period.

Despite the slurries from the autotrophic denitrification zone were collected from the same depth interval, these samples exhibited not only a large variation of $\mathrm{N}_{2} \mathrm{O}$ concentrations during anaerobic incubation, but also distinct differences in organic carbon, total sulfur and texture. This demonstrates that the aquifer material obtained by our sampling procedure exhibited heterogeneous properties. For example, sample I1-6, the sample with the highest content of organic carbon and clay in the data-set (Table 1), did not show considerable accumulation of $\mathrm{N}_{2} \mathrm{O}$ during the entire experiment and exhibited the lowest $c \mathrm{~N}_{2} \mathrm{O}_{\text {max }}$-to- $\left(\mathrm{N}_{2} \mathrm{O}+\mathrm{N}_{2}\right)$ ratio (Fig. 3, Table 2). Furthermore, this sample showed by far the highest $D_{i} . c \mathrm{~N}_{2} \mathrm{O}_{\max }$ of the sample I1-10 was $77 \mu \mathrm{g} \mathrm{N} \mathrm{N}_{2} \mathrm{O}$ $\mathrm{N} \mathrm{kg}^{-1}$ and thus comparable with the highest $c \mathrm{~N}_{2} \mathrm{O}_{\max }$ values we observed in the samples of the heterotrophic denitrification zone. Apart from these two samples, all the other ones were characterized by considerably higher $c \mathrm{~N}_{2} \mathrm{O}_{\max }$ values (Fig. 3, Table 2) between $239 \mu \mathrm{g} \mathrm{N}_{2} \mathrm{O}-\mathrm{N} \mathrm{kg}^{-1}$ (sample I1-5) and $1698 \mu \mathrm{g} \mathrm{N}_{2} \mathrm{O}-\mathrm{N} \mathrm{kg}^{-1}$ (sample I1-4). 

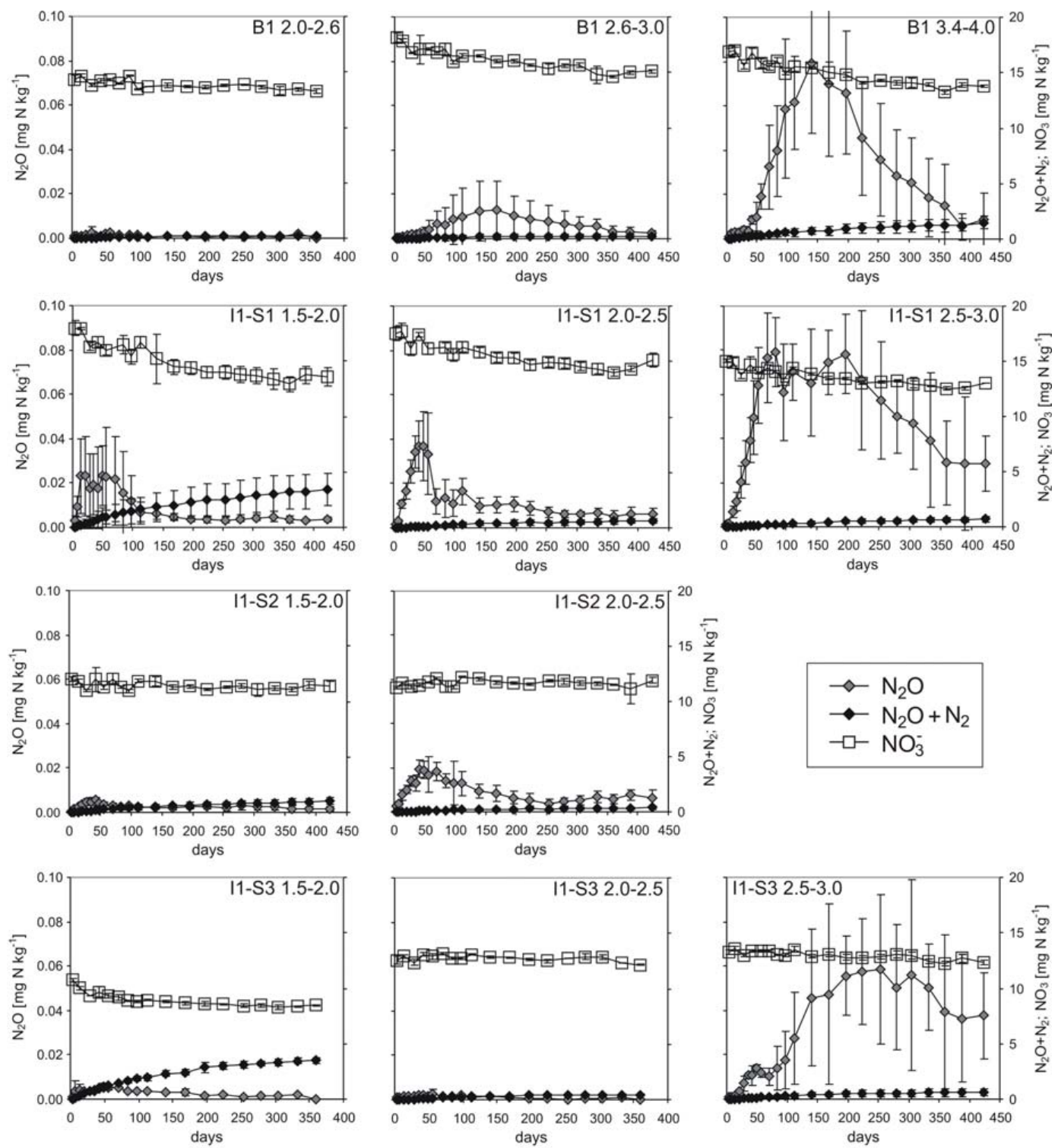

Fig. 2. Concentration courses of $\mathrm{N}_{2} \mathrm{O}, \mathrm{N}_{2} \mathrm{O}+\mathrm{N}_{2}$, and $\mathrm{NO}_{3}^{-}$during long-term anaerobic incubation of aquifer material from the heterotrophic denitrification zone. The symbols denote the means of 4 replications and the error bars represent the standard deviation.

We observed considerable formation of $\mathrm{SO}_{4}^{2-}$ during incubation of the aquifer slurries from the autotrophic denitrification zone. $\mathrm{SO}_{4}^{2-}$ production rates converted to $\mathrm{N}$ equivalents ranged between 36 and $185 \mu \mathrm{g} \mathrm{N}^{-1} \mathrm{~kg}^{-1} \mathrm{~d}^{-1}$ and were in good agreement with the denitrification rates (Table 2), i.e. were found to be between $D_{i}$ and $D_{\max }$ for the majority of the samples. However, sample I1-4 exhibited a lower and sample I1-6 a slightly higher $\mathrm{SO}_{4}^{2-}$ production rate than predicted by the denitrification rates.

The $\mathrm{pH}$ was monitored throughout the entire incubation experiments. Typical ranges were between 4.2 and 5.9. These values indicate similar acidic conditions which we also found in the groundwater at the wells B1 and I1, respectively (Fig. 1f).
We conducted Spearman rank tests for the partial datasets of the heterotrophic and the autotrophic zone in order to evaluate correlations between the parameters that were introduced in Tables 1 and 2, respectively.

The correlation coefficients $\left(R_{\mathrm{S}}\right)$ for the relationships between $c \mathrm{~N}_{2} \mathrm{O}_{\text {max }}$, the $c \mathrm{~N}_{2} \mathrm{O}_{\text {max }}$-to- $\left(\mathrm{N}_{2} \mathrm{O}+\mathrm{N}_{2}\right)$ ratio, $D_{i}, D_{\max }$ and the independent soil properties are shown in Table 3 . In the case of heterotrophic denitrification, a significant correlation at the 0.05 probability level was found between organic carbon and $D_{i}$. The relationship between the waterextractable C-species (DOC, $C_{\mathrm{hws}}$ ) and the denitrification rates $\left(D_{i}, D_{\max }\right)$ did not reveal a significant correlation. However, the correlation coefficient for the relationship between $D_{i}$ and $C_{\mathrm{hws}}$ was comparatively high $\left(R_{\mathrm{S}}=0.55\right)$. In 

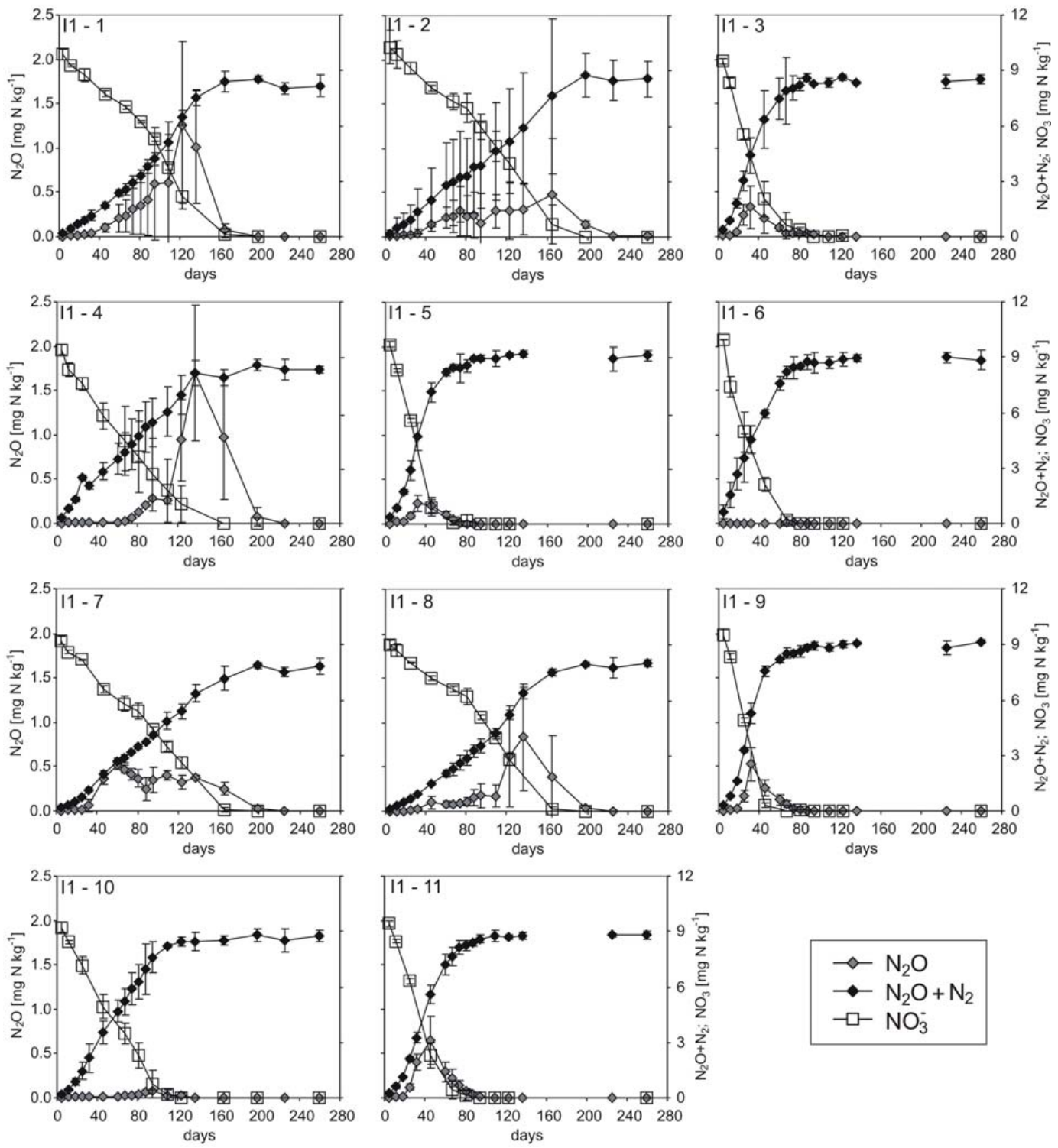

Fig. 3. Concentration courses of $\mathrm{N}_{2} \mathrm{O}, \mathrm{N}_{2} \mathrm{O}+\mathrm{N}_{2}$, and $\mathrm{NO}_{3}^{-}$during long-term anaerobic incubation of aquifer material from the autotrophic denitrification zone. The symbols denote the means of 4 replications and the error bars represent the standard deviation.

contrast, DOC was negatively correlated with $c \mathrm{~N}_{2} \mathrm{O}_{\max }$ at the 0.01 probability level. In the case of autotrophic denitrification, the denitrification rates $\left(D_{i}, D_{\max }\right)$ were found to be significantly correlated with the total sulfur content of the aquifer material, but interestingly also with organic carbon. Organic carbon was highly correlated with the clay content, but not with total sulfur. DOC and $C_{\mathrm{hws}}$ did not correlate with $D_{i}$ and $D_{\max }$, respectively. Furthermore, we found no significant relations between $c \mathrm{~N}_{2} \mathrm{O}_{\max }$ and the other parameters of the "autotrophic" data set.

\subsection{Kinetic rate constants of $\mathrm{N}_{2} \mathrm{O}$ production and reduction}

All data sets with the calculated rate constants and the corresponding fitting parameters are listed in Table 4 (sequential 3-parameter fit) and Table 5 (1-step 3-parameter fit). As expected from the time courses of the $\mathrm{NO}_{3}^{-}$and the $\left(\mathrm{N}_{2} \mathrm{O}+\mathrm{N}_{2}\right)$ concentrations, the obtained rate constants were higher for autotrophic denitrification. The means for $k_{1}$ and $k_{2}$ showed a difference of about one order of magnitude, when the heterotrophic and the autotrophic process are compared (Table 4). The rate constants of autotrophic denitrification exhibited a larger variability (Tables 4 and 5). For example 
Table 2. Maximum $\mathrm{N}_{2} \mathrm{O}$ concentrations $\left(\mathrm{cN}_{2} \mathrm{O}_{\max }\right), \mathrm{cN}_{2} \mathrm{O}_{\max }$-to- $\left(\mathrm{N}_{2} \mathrm{O}+\mathrm{N}_{2}\right)$ ratio, and reaction rates $\left(D_{i}, D_{\max }, \mathrm{SO} \mathrm{O}_{4}^{2-} \mathrm{PR}\right)$ during anaerobic incubation. $D_{i}$ denotes the initial denitrification rate calculated at day 7. $D_{\max }$ is the maximum denitrification rate calculated for the time interval with the steepest increase of the $\left(\mathrm{N}_{2} \mathrm{O}+\mathrm{N}_{2}\right)$ curve. $\mathrm{SO}_{4}^{2-} \mathrm{PR}$ represents the sulfate production rate calculated for the samples from the autotrophic denitrification zone in $\mathrm{N}$ equivalents.

\begin{tabular}{|c|c|c|c|c|c|c|c|}
\hline \multirow{2}{*}{$\begin{array}{l}\text { Sample } \\
\text { location }\end{array}$} & \multirow{2}{*}{$\begin{array}{l}\text { Depth interval } \\
{[\mathrm{m}]}\end{array}$} & \multirow{2}{*}{$\begin{array}{l}\text { Dentrification } \\
\text { zone }\end{array}$} & \multirow{2}{*}{$\begin{array}{r}c \mathrm{~N}_{2} \mathrm{O}_{\max } \\
{\left[\mu \mathrm{g} \mathrm{N} \mathrm{kg}^{-1}\right]}\end{array}$} & \multirow{2}{*}{$c \underset{\text { ratio }}{c \mathrm{~N}_{2} \mathrm{O}_{\max }-\mathrm{to}-\left(\mathrm{N}_{2} \mathrm{O}+\mathrm{N}_{2}\right)}$} & $D_{i}$ & $D_{\max }$ & $\mathrm{SO}_{4}^{2-} \mathrm{PR}$ \\
\hline & & & & & \multicolumn{3}{|c|}{$\left[\mu \mathrm{N} \mathrm{kg}^{-1} \mathrm{~d}^{-1}\right]$} \\
\hline B1 & $2.0-2.6$ & "heterotrophic" & 2.37 & 0.027 & 0.46 & 2.70 & n.d. ${ }^{1}$ \\
\hline B1 & $2.6-3.0$ & & 12.75 & 0.069 & 0.59 & 2.46 & n.d. ${ }^{1}$ \\
\hline B1 & $3.4-4.0$ & & 79.32 & 0.110 & 3.35 & 13.33 & n.d. ${ }^{1}$ \\
\hline I1-S1 & $1.5-2.0$ & & 23.35 & 0.026 & 8.61 & 35.16 & n.d. ${ }^{1}$ \\
\hline I1-S1 & $2.0-2.5$ & & 36.79 & 0.379 & 1.12 & 3.97 & n.d. ${ }^{1}$ \\
\hline I1-S1 & $2.5-3.0$ & & 79.28 & 0.415 & 0.74 & 4.57 & n.d. ${ }^{1}$ \\
\hline I1-S2 & $1.5-2.0$ & & 5.50 & 0.026 & 1.61 & 11.93 & n.d. ${ }^{1}$ \\
\hline I1-S2 & $2.0-2.5$ & & 19.44 & 0.258 & 0.85 & 4.67 & n.d. ${ }^{1}$ \\
\hline I1-S3 & $1.5-2.0$ & & 5.32 & 0.004 & 13.33 & 30.60 & n.d. ${ }^{1}$ \\
\hline I1-S3 & $2.0-2.5$ & & 2.46 & 0.018 & 0.43 & 3.51 & n.d. ${ }^{1}$ \\
\hline I1-S3 & $2.5-3.0$ & & 58.53 & 0.118 & 0.22 & 6.52 & n.d. ${ }^{1}$ \\
\hline I1-1 & $6.5-7.0$ & "autotrophic" & 1257.95 & 0.195 & 43.19 & 77.04 & 60.66 \\
\hline I1-2 & $6.5-7.0$ & & 482.74 & 0.063 & 50.93 & 61.24 & 58.44 \\
\hline I1-3 & $6.5-7.0$ & & 330.47 & 0.075 & 84.65 & 177.63 & 125.90 \\
\hline I1-4 & $65 .-7.0$ & & 1698.03 & 0.208 & 78.43 & 166.55 & 41.64 \\
\hline I1-5 & $6.5-7.0$ & & 239.15 & 0.051 & 86.52 & 257.73 & 125.50 \\
\hline I1-6 & $6.5-7.0$ & & 11.07 & 0.001 & 148.05 & 156.57 & 184.60 \\
\hline I1-7 & $6.5-7.0$ & & 520.17 & 0.192 & 34.40 & 61.35 & 59.08 \\
\hline I1-8 & $6.5-7.0$ & & 836.24 & 0.131 & 30.30 & 39.71 & 36.01 \\
\hline I1-9 & $6.5-7.0$ & & 525.60 & 0.100 & 77.71 & 283.56 & 152.15 \\
\hline I1-10 & $6.5-7.0$ & & 77.32 & 0.010 & 41.52 & 100.42 & 90.41 \\
\hline I1-11 & $6.5-7.0$ & & 647.00 & 0.115 & 57.21 & 168.48 & 130.41 \\
\hline
\end{tabular}

1 n.d.: not determined

I1-6, the sample with the highest $D_{i}$ and practically no $\mathrm{N}_{2} \mathrm{O}$ accumulation, yielded an outstanding high value for $k_{2}$, indicating intensive $\mathrm{N}_{2} \mathrm{O}$ reduction.

To analyse the fitting results, we chose the data set "I1S2 2.0-2.5" as a representative example that is shown in Fig. 4. Since the time courses of $\mathrm{N}_{2} \mathrm{O}$ concentration result from the balance between production $\left(k_{1}\right)$ and reduction of $\mathrm{N}_{2} \mathrm{O}\left(k_{2}\right)$, i.e. between nitrate reduction and di-nitrogen production, one would expect that the rate constants describe consistently both the time course of nitrate (Eq. 6) and the time course of $\left(\mathrm{N}_{2} \mathrm{O}+\mathrm{N}_{2}\right)$ (Eq. 7). As shown in Fig. $4 \mathrm{~b}$, the 1-step 3-parameter fit underestimated the total concentration of the gaseous species. This clearly demonstrates the necessity of an independent measurement in order to prove the rate constants obtained by the kinetics describing the $\mathrm{N}_{2} \mathrm{O}$-curve. We emphasize that fitting for best agreement of measured and modeled $\mathrm{N}_{2} \mathrm{O}$ curves (compare 1-step 3-parameter fit in Fig. 4 with experimental data) did not yield a satisfactory agreement for the $\mathrm{NO}_{3}^{-}$and $\left(\mathrm{N}_{2} \mathrm{O}+\mathrm{N}_{2}\right)$ curves, respectively.
In order to ensure that the cumulative curve of $\left(\mathrm{N}_{2} \mathrm{O}+\mathrm{N}_{2}\right)$ is reproduced reasonable well, we used a second fitting procedure, namely the sequential fit, i.e. in a first fitting step we determined $k_{1}$ by the cumulative curve of $\mathrm{N}_{2} \mathrm{O}+\mathrm{N}_{2}$ and in a second step we determined $k_{2}$ by the $\mathrm{N}_{2} \mathrm{O}$-curve. As can be seen in Fig. 4b, we then obtained an excellent fit to the time course of $\left(\mathrm{N}_{2} \mathrm{O}+\mathrm{N}_{2}\right)$. However, the goodness of fit of the $\mathrm{N}_{2} \mathrm{O}$-data has been deteriorated (Fig. 4a), i.e. the early-time behaviour exhibits an increase that is too steep. Nevertheless, the profile in its entirety is still reasonably satisfactory.

As shown in Fig. 4c, both fitting approaches yielded a very low initial nitrate concentration which deviated considerably from the experimental data. The ratio of the theoretical and experimental initial concentration for the sample I1-S2 2.02.5 is 0.02 and 0.03 , respectively (Tables 4 and 5 ). In principle, one would use only the rate constants as fitting parameters, and vary the initial nitrate concentration. This was used as the starting point. For the sequential 2-parameter fit, the best fits are shown as dashed curves in Fig. 4. The agreement both to the $\mathrm{N}_{2} \mathrm{O}$ - and to the $\left(\mathrm{N}_{2} \mathrm{O}+\mathrm{N}_{2}\right)$ curves was insufficient, indicating that the constant $C_{0}$ (Eqs. 7-9) is not given 
Table 3. Spearman rank correlation coefficients between the parameters obtained from the laboratory incubation experiments for the heterotrophic and the autotrophic data set. Clay was not detectable in the aquifer material of the heterotrophic denitrification zone and was thus excluded from the correlation analysis.

\begin{tabular}{|c|c|c|c|c|c|c|c|c|c|c|}
\hline & $C_{\text {org }}$ & Total N & C-to- $\mathrm{N}$ ratio & DOC & $C_{\mathrm{hws}}$ & Total S & Clay & $c \mathrm{~N}_{2} \mathrm{O}_{\max }$ & $\begin{array}{c}c \mathrm{~N}_{2} \mathrm{O}_{\max } \text {-to- } \\
\left(\mathrm{N}_{2} \mathrm{O}+\mathrm{N}_{2}\right) \text { ratio }\end{array}$ & $D_{i}$ \\
\hline \multicolumn{11}{|c|}{ correlation coefficients between parameters of heterotrophic dentrification } \\
\hline Total N & $0.22 \mathrm{~ns}$ & & & & & & & & & \\
\hline C-to-N ratio & $0.27 \mathrm{~ns}$ & $-0.69^{2}$ & & & & & & & & \\
\hline DOC & $0.32 \mathrm{~ns}$ & $-0.34 \mathrm{~ns}$ & $0.65^{1}$ & & & & & & & \\
\hline$C_{\text {hws }}$ & $0.67^{1}$ & $0.69^{1}$ & $-0.17 \mathrm{~ns}$ & $0.45 \mathrm{~ns}$ & & & & & & \\
\hline Total S & $-0.15 \mathrm{~ns}$ & $0.44 \mathrm{~ns}$ & $-0.62^{1}$ & $0.44 \mathrm{~ns}$ & $0.33 \mathrm{~ns}$ & & & & & \\
\hline$c \mathrm{~N}_{2} \mathrm{O}_{\max }$ & $-0.08 \mathrm{~ns}$ & $0.51 \mathrm{~ns}$ & $-0.64^{1}$ & $-0.82^{2}$ & $0.02 \mathrm{~ns}$ & $0.34 \mathrm{~ns}$ & & & & \\
\hline$c \mathrm{~N}_{2} \mathrm{O}_{\text {max }}$-to- $\left(\mathrm{N}_{2} \mathrm{O}+\mathrm{N}_{2}\right)$ ratio & $-0.56^{1}$ & $0.12 \mathrm{~ns}$ & $-0.62^{1}$ & -0.681 & $-0.21 \mathrm{~ns}$ & $0.50 \mathrm{~ns}$ & & $0.69^{2}$ & & \\
\hline$D_{i}$ & $0.62^{2}$ & $0.24 \mathrm{~ns}$ & $0.32 \mathrm{~ns}$ & $0.19 \mathrm{~ns}$ & $0.55 \mathrm{~ns}$ & $-0.45 \mathrm{~ns}$ & & $0.15 \mathrm{~ns}$ & $-0.23 \mathrm{~ns}$ & \\
\hline$D_{\max }$ & $0.39 \mathrm{~ns}$ & $0.35 \mathrm{~ns}$ & $0.16 \mathrm{~ns}$ & $0.06 \mathrm{~ns}$ & $0.24 \mathrm{~ns}$ & $-0.42 \mathrm{~ns}$ & & $0.33 \mathrm{~ns}$ & $-0.28 \mathrm{~ns}$ & $0.74^{2}$ \\
\hline \multicolumn{11}{|c|}{ correlation coefficients between parameters of autotrophic dentrification } \\
\hline Total N & $0.33 \mathrm{~ns}$ & & & & & & & & & \\
\hline C-to-N ratio & $0.43 \mathrm{~ns}$ & $0.54^{1}$ & & & & & & & & \\
\hline DOC & $0.57^{1}$ & $0.15 \mathrm{~ns}$ & $0.29 \mathrm{~ns}$ & & & & & & & \\
\hline$C_{\mathrm{hws}}$ & $-0.38 \mathrm{~ns}$ & $-0.11 \mathrm{~ns}$ & $-0.20 \mathrm{~ns}$ & $-0.33 \mathrm{~ns}$ & & & & & & \\
\hline Total S & $0.15 \mathrm{~ns}$ & $0.13 \mathrm{~ns}$ & $-0.28 \mathrm{~ns}$ & $-0.22 \mathrm{~ns}$ & $0.19 \mathrm{~ns}$ & & & & & \\
\hline Clay & $0.82^{2}$ & $0.49 \mathrm{~ns}$ & $0.07 \mathrm{~ns}$ & $0.31 \mathrm{~ns}$ & $-0.43 \mathrm{~ns}$ & $0.47 \mathrm{~ns}$ & & & & \\
\hline$c \mathrm{~N}_{2} \mathrm{O}_{\max }$ & $-0.20 \mathrm{~ns}$ & $-0.35 \mathrm{~ns}$ & $0.04 \mathrm{~ns}$ & $0.11 \mathrm{~ns}$ & $0.15 \mathrm{~ns}$ & $-0.35 \mathrm{~ns}$ & $-0.48 \mathrm{~ns}$ & & & \\
\hline$c \mathrm{~N}_{2} \mathrm{O}_{\text {max }}$-to- $\left(\mathrm{N}_{2} \mathrm{O}+\mathrm{N}_{2}\right)$ ratio & $-0.19 \mathrm{~ns}$ & $-0.52 \mathrm{~ns}$ & $0.17 \mathrm{~ns}$ & $0.16 \mathrm{~ns}$ & $0.25 \mathrm{~ns}$ & $-0.38 \mathrm{~ns}$ & $-0.54^{1}$ & $0.94^{3}$ & & \\
\hline$D_{i}$ & $0.64^{1}$ & $0.66^{1}$ & $0.66^{1}$ & $0.15 \mathrm{~ns}$ & $0.10 \mathrm{~ns}$ & $0.53^{1}$ & $0.65^{1}$ & $-0.38 \mathrm{~ns}$ & $-0.42 \mathrm{~ns}$ & \\
\hline$D_{\max }$ & $0.65^{1}$ & $0.32 \mathrm{~ns}$ & $0.32 \mathrm{~ns}$ & $0.08 \mathrm{~ns}$ & $-0.08 \mathrm{~ns}$ & $0.52^{1}$ & $0.72^{2}$ & $-0.17 \mathrm{~ns}$ & $-0.21 \mathrm{~ns}$ & $0.73^{2}$ \\
\hline
\end{tabular}

${ }^{1}$ Correlation significant at the 0.05 probability level; ${ }^{2}$ correlation significant at the 0.01 probability level; ${ }^{3}$ correlation significatn at the 0.001 probability level; ns: not significant

by the initial nitrate concentration. This is also indicated by the magnitude of the deviation between the experimental data and the theoretical curve (Fig. 4c).

\section{Discussion}

\subsection{Field measurements reveal the zones of denitrification and $\mathrm{N}_{2} \mathrm{O}$ accumulation}

The special characteristic of the studied aquifer is the occurrence of the vertically separated process zones of heterotrophic and autotrophic denitrification. The results of the laboratory incubations showed that these processes generate a different nitrate removal efficiency and thus reaction kinetics. This was also confirmed in a recent study of Weymann et al. (2008) in the FFA by determining excess $\mathrm{N}_{2}$ depending on depth. Whereas excess $\mathrm{N}_{2}$ from denitrification was found to be low in the shallow groundwater, i.e. in the heterotrophic zone, the authors reported highest values for excess $\mathrm{N}_{2}$ (predominantly between 10 and $15 \mathrm{mg} \mathrm{N} \mathrm{L}^{-1}$ ) in depths beyond $5 \mathrm{~m}$ below the soil surface, i.e. in the autotrophic zone. Against this background, the question arises to what extent the different nitrate removal efficiencies influence the accumulation of $\mathrm{N}_{2} \mathrm{O}$ under field conditions. As the multilevel well measurements indicate, the different reaction kinetics of heterotrophic and autotrophic denitrification yielded a large range and a huge variability of $\mathrm{N}_{2} \mathrm{O}$ concentrations in the investigated in situ profiles at the wells B1 and I1 (Fig. 1b). More precisely, we identified a zone of considerable $\mathrm{N}_{2} \mathrm{O}$ accumulation close to the groundwater surface which has been already reported by Deurer et al. (2008). Elevated $\mathrm{N}_{2} \mathrm{O}$ concentrations were also found up to 2 to $3 \mathrm{~m}$ below the water table. A previous study has shown that this layer probably equates with the zone of heterotrophic denitrification (von der Heide et al., 2008). As the laboratory incubations indicate and Weymann et al. (2008) confirmed, this zone is characterised by low nitrate removal efficiency. The occurrence of $\mathrm{N}_{2} \mathrm{O}$ accumulation or $\mathrm{N}_{2} \mathrm{O}$ emission combined with low nitrate removal efficiency has also been described in other studies. Hefting et al. (2006) found significant $\mathrm{N}_{2} \mathrm{O}$ emissions along a flowpath with low nitrate removal efficiency in a riparian buffer zone. Van Cleemput (1998) stated that conditions causing an inhibition of denitrification, i.e. causing a low nitrate removal efficiency, are favourable for $\mathrm{N}_{2} \mathrm{O}$ accumulation. In this context, a key factor for heterotrophic denitrification is the availability of organic carbon. The sandy aquifer material of the FFA contains low amounts of organic carbon (Table 1) and the microbial bioavailability can be strongly assumed to be poor (Böttcher et al., 1991). Beside this, it is known that low $\mathrm{pH}$ and high $\mathrm{NO}_{3}^{-}$levels favour $\mathrm{N}_{2} \mathrm{O}$ accumulation due to inhibited $\mathrm{N}_{2} \mathrm{O}$ reduction to $\mathrm{N}_{2}$ (Blackmer and Bremner, 1978; van Cleemput, 1998; Šimek and 
Table 4. Rate constants for heterotrophic and autotrophic denitrification derived from the sequential 3-parameter fit. $R^{2}\left(k_{1}\right)$ and $R^{2}\left(k_{2}\right)$ denote the correlation coefficients for the $\left(\mathrm{N}_{2} \mathrm{O}+\mathrm{N}_{2}\right)$-data and the $\mathrm{N}_{2} \mathrm{O}$-data, respectively. The initial nitrate concentration $C_{0}$ was used as the third fitting parameter. The ratio of the fitting value and the experimental value is given in the last column and SD denotes the standard deviation.

\begin{tabular}{|c|c|c|c|c|c|c|c|}
\hline \multirow[t]{2}{*}{ Sample location } & \multirow{2}{*}{$\begin{array}{l}\text { Depth interval } \\
{[\mathrm{m}]}\end{array}$} & $k_{1}$ & $k_{2}$ & \multirow[t]{2}{*}{$R^{2}\left(k_{1}\right)$} & \multirow[t]{2}{*}{$R^{2}\left(k_{2}\right)$} & \multirow{2}{*}{$\begin{array}{c}C 0_{\text {fit }} \\
{\left[\mathrm{mg} \mathrm{N} \mathrm{kg}^{-1}\right]}\end{array}$} & \multirow[t]{2}{*}{$C 0_{\text {fit }} / C 0_{\exp }$} \\
\hline & & \multicolumn{2}{|c|}{ [days $^{-1}$ ] } & & & & \\
\hline B1 & $2.0-2.6$ & 0.007 & 0.977 & 1.000 & 0.740 & 0.263 & 0.018 \\
\hline B1 & $2.6-3.0$ & 0.008 & 0.263 & 1.000 & 0.270 & 0.226 & 0.012 \\
\hline B1 & $3.4-4.0$ & 0.004 & 0.162 & 1.000 & 0.430 & 1.698 & 0.101 \\
\hline I1-S1 & $1.5-2.0$ & 0.005 & 0.920 & 1.000 & 0.844 & 3.826 & 0.213 \\
\hline I1-S1 & $2.0-2.5$ & 0.004 & 0.115 & 1.000 & 0.840 & 0.714 & 0.041 \\
\hline I1-S1 & $2.5-3.0$ & 0.003 & 0.031 & 1.000 & 0.910 & 0.945 & 0.063 \\
\hline I1-S2 & $1.5-2.0$ & 0.004 & 1.172 & 1.000 & 0.830 & 1.174 & 0.098 \\
\hline $\mathrm{I} 1-\mathrm{S} 2$ & $2.0-2.5$ & 0.006 & 0.103 & 1.000 & 0.910 & 0.364 & 0.032 \\
\hline I1-S3 & $1.5-2.0$ & 0.007 & 4.881 & 1.000 & 0.850 & 3.768 & 0.350 \\
\hline I1-S3 & $2.0-2.5$ & 0.005 & 1.435 & 1.000 & 0.900 & 0.550 & 0.044 \\
\hline I1-S3 & $2.5-3.0$ & 0.005 & 0.100 & 1.000 & 0.270 & 0.687 & 0.052 \\
\hline mean & & 0.005 & 0.924 & 1.000 & 0.709 & 1.292 & 0.093 \\
\hline SD & & 0.001 & 1.407 & 0.000 & 0.255 & 1.310 & 0.102 \\
\hline I1-1 & $6.5-7.0$ & 0.004 & 0.135 & 0.980 & 0.370 & 15.340 & 1.550 \\
\hline I1-2 & $6.5-7.0$ & 0.003 & 0.230 & 1.000 & 0.580 & 18.880 & 1.840 \\
\hline I1-3 & $6.5-7.0$ & 0.020 & 1.145 & 0.990 & 0.390 & 9.680 & 1.020 \\
\hline I1-4 & $6.5-7.0$ & 0.008 & 0.289 & 0.990 & 0.100 & 10.120 & 1.080 \\
\hline I1-5 & $6.5-7.0$ & 0.019 & 1.824 & 0.990 & 0.330 & 10.490 & 1.080 \\
\hline I1-6 & $6.5-7.0$ & 0.021 & 35.320 & 1.000 & 0.400 & 9.950 & 1.000 \\
\hline I1-7 & $6.5-7.0$ & 0.004 & 0.154 & 1.000 & 0.610 & 12.860 & 1.390 \\
\hline I1-8 & $6.5-7.0$ & 0.002 & 0.239 & 0.980 & 0.300 & 22.140 & 2.460 \\
\hline I1-9 & $6.5-7.0$ & 0.021 & 1.157 & 0.990 & 0.270 & 10.140 & 1.060 \\
\hline I1-10 & $6.5-7.0$ & 0.012 & 3.578 & 0.990 & 0.320 & 9.799 & 1.060 \\
\hline I1-11 & $6.5-7.0$ & 0.014 & 0.621 & 0.990 & 0.330 & 11.250 & 1.190 \\
\hline mean & & 0.012 & 4.063 & 0.991 & 0.364 & 12.786 & 1.339 \\
\hline SD & & 0.008 & 10.418 & 0.007 & 0.140 & 4.237 & 0.456 \\
\hline
\end{tabular}

Cooper, 2002). In the case of the FFA, it has been previously assumed that the $\mathrm{pH}$ of $<5.5$ (Deurer et al., 2008), intermediate $\mathrm{O}_{2}$ concentrations below $3.15 \mathrm{mg} \mathrm{L}^{-1}$ (Deurer et al., 2008), and the high $\mathrm{NO}_{3}^{-}$concentrations (von der Heide et al., 2008) are further factors supporting the accumulation of $\mathrm{N}_{2} \mathrm{O}$ in the near-surface groundwater of the FFA in addition to the low availability of organic organic carbon. Confirming the results of Hefting et al. (2006) and van Cleemput (1998), we can thus conclude that the combination of (i) the limited carbon (bio)availability, (ii) the low $\mathrm{pH}$ (Fig. 1f), (iii) intermediate $\mathrm{O}_{2}$ concentrations (Fig. 1e) and (iv) elevated $\mathrm{NO}_{3}^{-}$concentrations (Fig. 1a) explains the low nitrate removal efficiency in the near-surface groundwater as well as the considerable $\mathrm{N}_{2} \mathrm{O}$ accumulation. Since $\mathrm{N}_{2} \mathrm{O}$ concentrations in the unsaturated zone above the groundwater table are low, i.e. similar to ambient $\mathrm{N}_{2} \mathrm{O}$ concentrations (von der Heide et al., 2009; Weymann et al., 2009), we want to emphasize that the described $\mathrm{N}_{2} \mathrm{O}$ accumulation is a result of the in situ production in the groundwater. In contrast, the unsaturated zone was identified as an $\mathrm{N}_{2} \mathrm{O}$ source for British limestone aquifers (Mühlherr and Hiscock, 1998).

As mentioned in Sect. 3.1, we observed a sharp $\mathrm{N}_{2} \mathrm{O}$ concentration peak in both profiles in the autotrophic denitrification zone in depths of $5 \mathrm{~m}$ and $6 \mathrm{~m}$, respectively (Fig. 1). In contrast to heterotrophic denitrification, the nitrate removal in the autotrophic process zone is much more intensive. This has been revealed by the results of the laboratory incubations and was shown previously (Frind et al., 1990; Weymann et al., 2008). Due to the low nitrate removal efficiency in the heterotrophic denitrification zone, the $\mathrm{NO}_{3}^{-}$load of the groundwater was still high (concentrations between 11 and $23 \mathrm{mg} \mathrm{N} \mathrm{L}^{-1}$ ) when it came in contact with the pyrite present in the autotrophic denitrification zone. Accordingly, $\mathrm{N}_{2} \mathrm{O}$ was produced within an intensive nitrate removal caused by autotrophic denitrification. But, in contrast to the $\mathrm{N}_{2} \mathrm{O}$ accumulation in the near-surface groundwater, we assume that the sharp $\mathrm{N}_{2} \mathrm{O}$ concentration peak in both profiles is an indicator for rapid $\mathrm{N}_{2} \mathrm{O}$ reduction which hampered an accumulation 
of $\mathrm{N}_{2} \mathrm{O}$ in the sense of the heterotrophic denitrification zone. Finally, the high nitrate removal efficiency in the autotrophic denitrification zone resulted in a complete reduction of $\mathrm{NO}_{3}^{-}$ and $\mathrm{N}_{2} \mathrm{O}$ in depths below $5 \mathrm{~m}$ and $6 \mathrm{~m}$, respectively. Thus, the autotrophic denitrification zone clearly functioned as a sink for $\mathrm{N}_{2} \mathrm{O}$. This is comparable with the findings of BlicherMathiesen and Hoffmann (1999) who reported an effective nitrate removal in a riparian fen without $\mathrm{N}_{2} \mathrm{O}$ accumulation. It is important to note that the high nitrate removal efficiency in the autotrophic denitrification zone is most likely caused by practically anoxic conditions (Fig. 1e) and the high reactivity of the microcrystalline pyrite components (Kölle et al., 1985). Rivett et al. (2008) also identified $\mathrm{O}_{2}$ and electron donor concentration and availability as the primary factors governing denitrification in groundwater. Furthermore, these authors pointed out that reduced iron $\left(\mathrm{Fe}^{2+}\right)$ may serve as an electron donor for autotrophic denitrification in groundwater. Kölle et al. (1983) showed that there is some evidence for this reaction in the FFA. However, the mediating bacterium Gallionella ferruginea does require a small amount of $\mathrm{O}_{2}$ for growth (Rivett et al., 2008) which is not a condition that is implicitly true for the predominantly anoxic autotrophic denitrification zone of the FFA. Since sulfate production and denitrification of nitrate obtained from the laboratory incubations are mostly in satisfactory agreement, we assume that reduced iron is probably of minor importance as an electron donor for denitrification compared to pyrite.

In summary, the vertical courses of $\mathrm{NO}_{3}^{-}$and $\mathrm{N}_{2} \mathrm{O}$ concentrations at the investigated wells plausibly reflect the occurrence of the separated denitrification zones in the aquifer. Taking the $\mathrm{SO}_{4}^{2-}$ concentrations into account (Fig. 1c), this conception is only confirmed by the gradient of I1. At this well, the increase of the $\mathrm{SO}_{4}^{2-}$ concentrations reflect the considerable sulfate formation capacity of the autotrophic zone (Table 2; Kölle et al., 1985). This was not observed at well B1. Low potassium concentrations between 2.0 and $2.5 \mathrm{mg} \mathrm{L}^{-1}$ (well I1: typically 13.5 -to- $17.0 \mathrm{mg} \mathrm{L}^{-1}$ ) indicate that the aquifer at this well is recharged by groundwater that infiltrated at forest or pasture areas. This groundwater is characterised by significantly lower concentrations of $\mathrm{SO}_{4}^{2-}$, $\mathrm{N}_{2} \mathrm{O}$, and $\mathrm{NO}_{3}^{-}$than groundwater under arable land (von der Heide et al., 2008). Hence, we assume that dilution attenuated the concentrations of the investigated parameters in the autotrophic denitrification zone at well B1. Furthermore, we found comparatively high $\mathrm{SO}_{4}^{2-}$ concentrations in the nearsurface groundwater at the well B1 (Fig. 1c). This can be attributed to the intensive use of fertilisers containing sulfate $\left(\left(\mathrm{NH}_{4}\right) 2 \mathrm{SO}_{4} ;\left(\mathrm{NH}_{4}\right) 2 \mathrm{SO}_{4} \cdot \mathrm{NH}_{4} \mathrm{NO}_{3}\right.$; Hansen, 2005). Thus, we do not interpret those high $\mathrm{SO}_{4}^{2-}$ concentrations as a result of autotrophic denitrification, because of the exhaustion of pyrite in the near-surface groundwater (von der Heide et al., 2008).
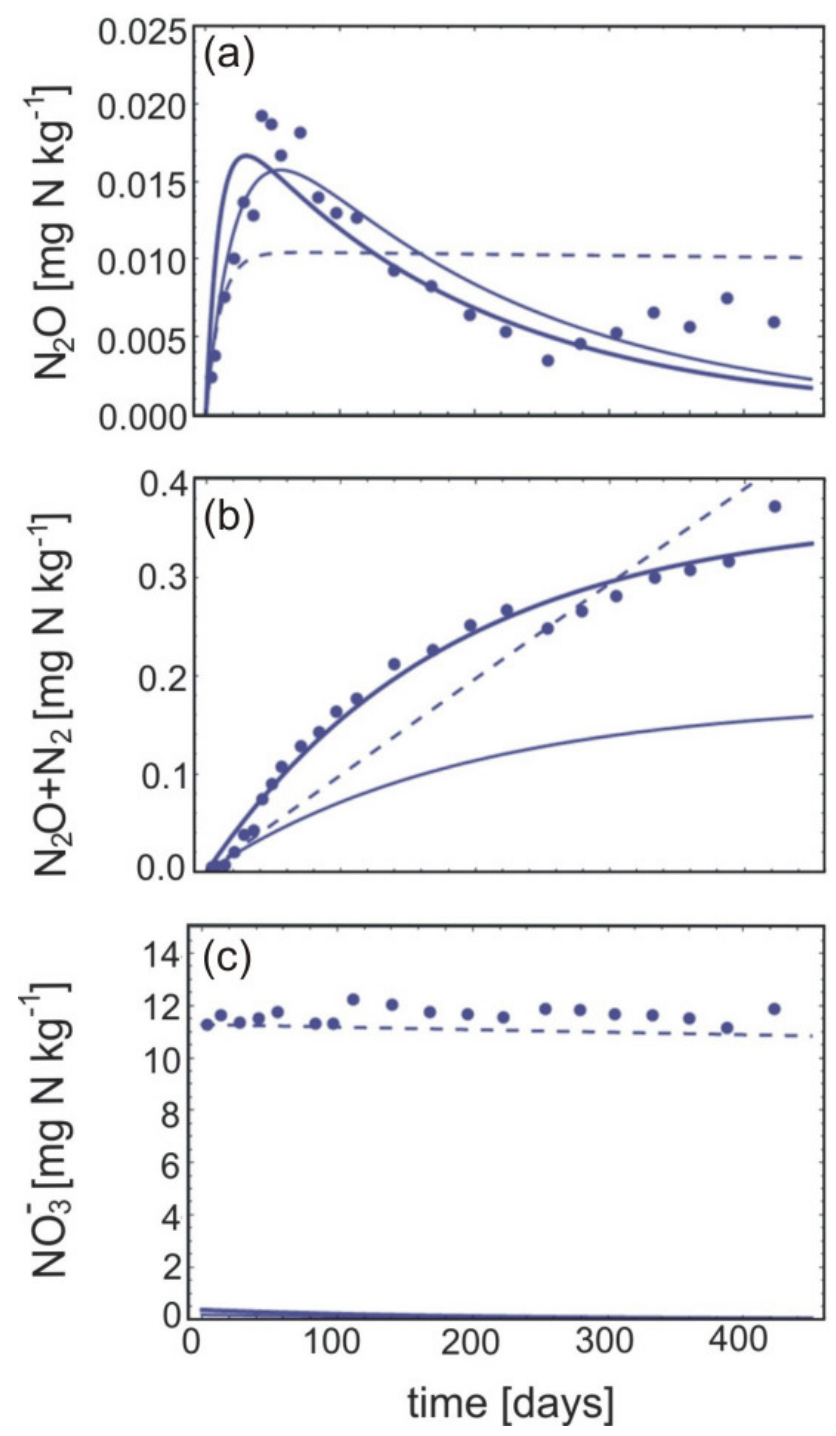

Fig. 4. Comparison between experimental $\mathrm{N}_{2} \mathrm{O}-\left(\right.$ a), $\left(\mathrm{N}_{2} \mathrm{O}+\mathrm{N}_{2}\right)$ (b), and $\mathrm{NO}_{3}^{-}$(c) concentrations (solid circles) and fitting curves (thick solid line: sequential 3-parameter fit; thin solid line: 1-step 3-parameter fit; dashed line: sequential 2-parameter fit) for the data set I1-S2 2.0-2.5 (heterotrophic denitrification). The rate constants $k_{1}$ and $k_{2}$ as well as the initial nitrate concentration $C_{0}$ were used as fitting parameters for the 3-parameter fits.

\subsection{Kinetics of $\mathrm{N}_{2} \mathrm{O}$ production and reduction during long-term laboratory incubation}

The results showed convincingly the substantial difference between the $\mathrm{N}_{2} \mathrm{O}$ kinetics of heterotrophic and autotrophic denitrification. Among the factors governing denitrification, the initial $\mathrm{NO}_{3}^{-}$concentration, anaerobic conditions, and $\mathrm{pH}$ were similar for the heterotrophic and the autotrophic aquifer material during anaerobic incubation. Variation in process dynamics between the heterotrophic and the autotrophic process was thus mainly caused by the differences in the electron 
Table 5. Rate constants for heterotrophic and autotrophic denitrification derived from the 1-step 3-parameter fit. $R^{2}$ denotes the correlation coefficient.The initial nitrate concentration $C_{0}$ was used as third fitting parameter. The initial nitrate concentration $C_{0}$ was used as the third fitting parameter. The ratio of the fitting value and the experimental value is given in the last column and SD denotes the standard deviation.

\begin{tabular}{|c|c|c|c|c|c|c|}
\hline \multirow[t]{2}{*}{ Sample location } & \multirow{2}{*}{$\begin{array}{c}\text { Depth interval } \\
{[\mathrm{m}]}\end{array}$} & $k_{1}$ & $k_{2}$ & \multirow[t]{2}{*}{$R^{2}$} & \multirow{2}{*}{$\begin{array}{c}C 0_{\text {fit }} \\
{\left[\mathrm{mg} \mathrm{N} \mathrm{kg}^{-1}\right.}\end{array}$} & \multirow[t]{2}{*}{$C 0_{\text {fit }} / C 0_{\exp }$} \\
\hline & & \multicolumn{2}{|c|}{ days $^{-1}$ ] } & & & \\
\hline B1 & $2.0-2.6$ & 0.003 & 0.113 & 0.860 & 0.063 & 0.004 \\
\hline B1 & $2.6-3.0$ & 0.006 & 0.006 & 0.920 & 0.023 & 0.001 \\
\hline B1 & $3.4-4.0$ & 0.007 & 0.007 & 0.830 & 0.127 & 0.008 \\
\hline $\mathrm{I} 1-\mathrm{S} 1$ & $1.5-2.0$ & 0.010 & 0.070 & 0.950 & 0.206 & 0.011 \\
\hline I1-S1 & $2.0-2.5$ & 0.008 & 0.050 & 0.880 & 0.230 & 0.013 \\
\hline I1-S1 & $2.5-3.0$ & 0.007 & 0.007 & 0.970 & 0.195 & 0.013 \\
\hline $\mathrm{I} 1-\mathrm{S} 2$ & $1.5-2.0$ & 0.003 & 0.091 & 0.950 & 0.154 & 0.013 \\
\hline $\mathrm{I} 1-\mathrm{S} 2$ & $2.0-2.5$ & 0.005 & 0.044 & 0.960 & 0.175 & 0.016 \\
\hline $\mathrm{I} 1-\mathrm{S} 3$ & $1.5-2.0$ & 0.005 & 0.078 & 0.960 & 0.087 & 0.008 \\
\hline I1-S3 & $2.0-2.5$ & 0.006 & 0.061 & 0.960 & 0.025 & 0.002 \\
\hline I1-S3 & $2.5-3.0$ & 0.003 & 0.003 & 0.950 & 0.130 & 0.010 \\
\hline mean & & 0.006 & 0.048 & 0.926 & 0.129 & 0.009 \\
\hline SD & & 0.002 & 0.038 & 0.048 & 0.072 & 0.005 \\
\hline I1-1 & $6.5-7.0$ & 0.010 & 0.010 & 0.560 & 1.140 & 0.120 \\
\hline I1-2 & $6.5-7.0$ & 0.009 & 0.009 & 0.810 & 0.660 & 0.060 \\
\hline I1-3 & $6.5-7.0$ & 0.038 & 0.038 & 0.690 & 0.460 & 0.050 \\
\hline I1-4 & $6.5-7.0$ & 0.006 & 0.006 & 0.370 & 1.110 & 0.120 \\
\hline I1-5 & $6.5-7.0$ & 0.036 & 0.036 & 0.610 & 0.310 & 0.030 \\
\hline I1-6 & $6.5-7.0$ & 0.006 & 87.010 & 0.500 & 57.710 & 5.800 \\
\hline I1-7 & $6.5-7.0$ & 0.013 & 0.013 & 0.830 & 0.920 & 0.100 \\
\hline I1-8 & $6.5-7.0$ & 0.007 & 0.007 & 0.470 & 0.630 & 0.070 \\
\hline I1-9 & $6.5-7.0$ & 0.038 & 0.038 & 0.530 & 0.520 & 0.050 \\
\hline I1-10 & $6.5-7.0$ & 0.015 & 0.015 & 0.650 & 0.080 & 0.010 \\
\hline I1-11 & $6.5-7.0$ & 0.029 & 0.029 & 0.580 & 0.690 & 0.070 \\
\hline mean & & 0.019 & 7.928 & 0.600 & 5.839 & 0.589 \\
\hline SD & & 0.014 & 26.228 & 0.139 & 17.207 & 1.729 \\
\hline
\end{tabular}

donors, i.e. organic carbon and pyrite and their microbial availability.

We attribute the low activity of heterotrophic denitrification to the limited supply of organic carbon due to its low content and poor microbial availability, respectively. This is supported by $\mathrm{NO}_{3}^{-}$concentrations that remained close to initial concentrations during the incubation period, indicating that the electron acceptor was not a limiting factor for the process. Carbon limitation in sand and gravel aquifers was also demonstrated by Smith and Duff (1988), Obenhuber and Lowrance (1991) and Paramasivam et al. (1999). In fact, the organic carbon content in the samples of the heterotrophic zone was very low (Table 1) compared to the results of other incubation studies (Paramasivam et al., 1999; Well et al., 2005a). Besides the $\mathrm{NO}_{3}^{-}$analyses, we regularly measured DOC concentrations in the "heterotrophic" water samples (data not shown). Initial concentrations were found to be between 6 and $25 \mathrm{mg} \mathrm{C} \mathrm{L}^{-1}$ and were predominantly higher than the critical lower threshold of about
2-7 $\mathrm{mg} \mathrm{C} \mathrm{L}^{-1}$ that was reported to be necessary to promote denitrification (Spalding et al., 1978; Groffman et al., 1996). We did not observe significant DOC consumption within the whole incubation period in any sample of the heterotrophic zone. Furthermore, the correlation analysis yielded no significant relationships between extractable DOC and the denitrification rates (Table 3). Both findings indicate a poor bioavailability of DOC for denitrification in the heterotrophic zone, supporting the results of a previous field study in the FFA (Deurer et al., 2008) as well as the results of Jacinthe et al. (1998) and Siemens et al. (2003). We assume that labile, bioavailable DOC fractions were consumed in the unsaturated soil before entering the groundwater as it was shown for subsoils (McCarty and Bremner, 1992). However, von der Heide et al. (2010) reported significant negative correlations between DOC and $\mathrm{N}_{2} \mathrm{O}$ concentrations in the nearsurface groundwater of the FFA, a relationship that was also observed in this study (Table 3). The authors attributed this relationship to a promotion of $\mathrm{N}_{2} \mathrm{O}$ accumulation by 
decreasing bioavailability of DOC. This would require that DOC functions as an electron donor for the $\mathrm{NO}_{3}^{-}$-to- $\mathrm{N}_{2} \mathrm{O}$ step of denitrification, but to lesser extent for the $\mathrm{N}_{2} \mathrm{O}$-to- $\mathrm{N}_{2}$ step. As our data supply no evidence to confirm or contradict this, further research into the effect of DOC on $\mathrm{N}_{2} \mathrm{O}$ accumulation in groundwater is needed.

In contrast to heterotrophic denitrification, the autotrophic process was not limited by its electron donor pyrite, but by its electron acceptor $\mathrm{NO}_{3}^{-}$. The availability of pyrite was sufficient to eliminate $\mathrm{NO}_{3}^{-}$and $\mathrm{N}_{2} \mathrm{O}$ completely in all samples. Hence, we stress that the laboratory incubations also confirm the role of autotrophic denitrification to function as a sink for $\mathrm{NO}_{3}^{-}$and $\mathrm{N}_{2} \mathrm{O}$.

The aquifer material of the autotrophic zone was more variable in texture and organic carbon than the homogeneous sands of the heterotrophic zone (Table 1). The samples with the highest contents of organic carbon and clay, i.e. I1-5, I16 and I1-9, respectively, showed the highest denitrification activity (Fig. 3). These observations and the positive correlation between organic carbon and the "autotrophic" denitrification rates (Table 3) indicate that the kinetics of denitrification was apparently governed by these parameters. Against this background, the question arises whether heterotrophic denitrification also occurs in the autotrophic denitrification zone. On the one hand, lignitic pebbles which are nonuniformly distributed throughout the aquifer (Frind et al., 1990), could function as "patchy" hot spots (Parkin, 1987; Jacinthe et al., 1998; Gold et al., 1998) providing organic carbon serving as the electron donor and probably causing the small scale spatial variability of denitrification activity and $\mathrm{N}_{2} \mathrm{O}$ accumulation (von der Heide et al., 2010). This organic carbon is also used as an electron donor to reduce sulfate in the deeper groundwater of the FFA (Böttcher et al., 1989; Frind et al., 1990). Korom (1991) showed thermodynamically, that organic carbon used as an electron donor in the sulfatereducing zone of the FFA would preferentially be used by bacteria for heterotrophic denitrification. On the other hand, Böttcher et al. (1991) stated that as long as pyrite is available in the FFA, simultaneous heterotrophic denitrification is unlikely for several reasons. For example, the authors emphasized that the microbial availability of the organic lignitic pebbles is probably poor and might superimpose the thermodynamic "advantage" of heterotrophic denitrification. The similar rates of $\mathrm{SO}_{4}^{2-}$ production and denitrification (Table 2) seem to support this assumption and confirm ongoing autotrophic denitrification for the samples from the autotrophic denitrification zone. However, sample I1-4 indicated that there is also potential for heterotrophic denitrification because the denitrification rates $D_{i}$ and $D_{\max }$ can not be completely explained by the comparatively lower $\mathrm{SO}_{4}^{2-}$ production rate. Hence, the reactivity of the lignitic pebbles and the question, to what extent a possible heterotrophic process in the autotrophic denitrification zone contributes to total denitrification, remain subjects of uncertainty.
$\mathrm{NO}_{2}^{-}$did not accumulate during our incubation experiments, i.e. it was not detectable in any of the samples which were simultaneously analysed for $\mathrm{NO}_{3}^{-}$. We attribute this phenomenon to the $\mathrm{pH}$, which was typically between 4.2 and 5.9 throughout the entire incubation experiments (data not shown). Van Cleemput (1998) stated that $\mathrm{NO}_{2}^{-}$accumulation is favoured by high $\mathrm{pH}$ and high ammonium concentrations and - vice versa - is not stable in the presence of converse conditions $(\mathrm{pH}<6.0)$. Furthermore, Laverman et al. (2010) did not observe $\mathrm{NO}_{2}^{-}$production in batch experiments during incubation of river sediment slurries. $\mathrm{NO}$ as the precursor of $\mathrm{N}_{2} \mathrm{O}$ is a further possible intermediate in the denitrification reaction chain. However, Firestone and Davidson (1989) reported that very little, if any NO, was detected as a product of denitrifying cultures. For soils, several studies revealed that NO from soils is mainly produced by nitrification of ammonium while $\mathrm{N}_{2} \mathrm{O}$ mainly originates from the denitrification of nitrate (Davidson et al., 1993; Skiba et al., 1997; Russow et al., 2008). Furthermore, laboratory incubation experiments based on a kinetic ${ }^{15} \mathrm{~N}$ isotope method did not reveal NO as a free intermediate in the denitrification pathway (Russow et al., 2000). This is attributed to the limitation of diffusion in soil environments with high water content, i.e. to conditions favouring denitrification. NO produced is therefore rapidly reduced before it can escape from the cells (Skiba et al., 1997). We conclude that such "diffusion limitation" is even more valid for our laboratory approach with saturated aquifer slurries and that accumulation of NO was very unlikely. Since there is no evidence for the occurrence of $\mathrm{NO}_{2}^{-}$ and NO during our incubation experiments, we argue that the simplified two-step model of the denitrification pathway (Eq. 3) is valid for our laboratory approach.

Kinetic constants $k_{1}$ and $k_{2}$ of the first-order approach roughly reflected the different reaction rates of heterotrophic and autotrophic denitrification, as a comparison of their mean values revealed (Tables 4 , and 5). The outstanding high $k_{2}-$ value in the case of sample I1-6 reflects the fact that the balance between $\mathrm{N}_{2} \mathrm{O}$ production and reduction was clearly at the reduction side, yielding negligible $\mathrm{N}_{2} \mathrm{O}$ accumulation. Here, the rate constants also described the experimental data plausibly. However, in most cases the goodness of fit as given by $R^{2}$ of $k_{2}$ was not satisfactory. This can also be seen from the strong deviation between fitted and measured initial $\mathrm{NO}_{3}^{-}$concentration (Tables 4 , and 5). The initial nitrate concentration fitted by the 3-parameter fits $\left(C_{0}\right.$; Tables 4 , and 5) was much too low and not in agreement with the experimental data for the samples of heterotrophic denitrification (example in Fig. 4c). We assume that the exhaustion of available organic carbon is the reason for this deviation, because organic carbon was not taken into account by the model as a factor that limited the reaction. Instead, the first-order model assumed that process rates were controlled by the decreasing availability of $\mathrm{NO}_{3}^{-}$which did not occur during our experiments due to the poor nitrate removing efficiency of heterotrophic denitrification. Furthermore, the 
predominantly linear time courses of $\mathrm{NO}_{3}^{-}$and $\left(\mathrm{N}_{2} \mathrm{O}+\mathrm{N}_{2}\right)$ during autotrophic denitrification (Fig. 3) indicate that the reaction kinetics is rather described by a zero-order than by a first-order model. Pätsch (2006) and Konrad (2007) reported in agreement that both kinetics can occur in one aquifer. Therefore, using only one modeling approach may include uncertainties (Pätsch, 2006) and an improved model should be flexible enough to include both reaction types.

These considerations reveal that for an improved modeling approach (i) the electron donors have to be taken into account and (ii) zero-order and Michaelis-Menten kinetics should also be applied in order to describe production and reduction of $\mathrm{N}_{2} \mathrm{O}$ more precisely. Moreover, an improved approach should also be able to incorporate the kinetics of $\mathrm{NO}_{2}^{-}$reductase and $\mathrm{NO}$ reductase and to take into account $\mathrm{pH}$ and $\mathrm{O}_{2}$ as governing parameters. This would enlarge the flexibility of the model and thus its applicability to a wider range of environmental conditions.

\subsection{Transferability of laboratory incubations to field conditions}

Did the laboratory experiments and the respective kinetic constants reflect denitrification and $\mathrm{N}_{2} \mathrm{O}$ accumulation which are present in the groundwater? This question is generally subject to an ongoing controversy in groundwater literature, about whether or not batch experiments effectively describe field scale reactions (Dykaar and Kitanides, 1996; Ginn et al., 2002; McQuarrie and Sudicky, 2001). Kelly et al. (1996) showed by a comparison between derived kinetic parameters from batch experiments and column experiments that the derived kinetic constants deviated significantly. For example, column experiments yielded $V_{\max }$-values for Benzene between 0.037 and $0.219 \mathrm{1} / \mathrm{h}$, but a batch-experiment revealed a $V_{\max }$-value that was $0.0491 / \mathrm{h}$. On the other hand, Schirmer et al. (2000) had shown that kinetics derived from batch experiments can describe an in situ tracer test. As already mentioned in the introduction section, the question of transferability led also to conflicting statements related to denitrification and to the occurrence of $\mathrm{N}_{2} \mathrm{O}$ (Hénault et al., 2001; Obenhuber and Lowrance, 1991; Blicher-Mathiesen and Hoffmann, 1999; Well et al., 2003). Thus, to find an unambiguous and general answer seems to be impossible. Taking the present results of this study into account, it becomes obvious that we have to distinguish between heterotrophic and autotrophic denitrification if the transferability of the laboratory incubations should be assessed.

The different denitrification capacities of the heterotrophic and autotrophic zones in the FFA were reflected by the incubation experiments. The anaerobic incubations showed only marginal nitrate removal efficiency in the heterotrophic zone. In contrast, the rapid nitrate removal related to autotrophic denitrification yielded a capacity that is about one order of magnitude higher. Both observations are in agreement with the in situ concentration gradients (Fig. 1a) and with a previous field study (Weymann et al., 2008). Hence, this finding confirms the results of Well et al. (2003) who also reported a satisfactory agreement of laboratory and in situ measurements of denitrification.

If we regard the occurrence of $\mathrm{N}_{2} \mathrm{O}$, the subject of transferability has to be considered more differentially. For the autotrophic zone that was investigated at well I1, the field measurements yielded a maximum $\mathrm{N}_{2} \mathrm{O}$ concentration of $1.05 \mathrm{mg} \mathrm{NL}^{-1}$ at a depth of $6 \mathrm{~m}$ (Fig. 1) which equates to $0.26 \mathrm{mg} \mathrm{N} \mathrm{kg}^{-1}$ assuming a pore volume of $40 \%$. The median of the $c \mathrm{~N}_{2} \mathrm{O}_{\max }$ values measured during laboratory incubation (Table 2) was $0.52 \mathrm{mg} \mathrm{N} \mathrm{kg}^{-1}$. This comparison shows that laboratory and field data were in one order of magnitude and thus in satisfactory agreement. Furthermore, laboratory and field investigations showed correspondingly that the autotrophic zone functions as a sink for $\mathrm{N}_{2} \mathrm{O}$ if the $\mathrm{NO}_{3}^{-}$pool is exhausted, since $\mathrm{N}_{2} \mathrm{O}$ was completely consumed during the last stage of denitrification progress (Figs. 1 and 3). On the other hand, $c \mathrm{~N}_{2} \mathrm{O}_{\max }$ measured during laboratory incubation of the heterotrophic aquifer material were considerably lower than the maximum $\mathrm{N}_{2} \mathrm{O}$ concentrations we evaluated in the field. Whereas the median of the $\mathrm{cN}_{2} \mathrm{O}_{\max }$ values measured during laboratory incubation (Table 2) was $0.02 \mathrm{mg} \mathrm{N} \mathrm{kg}^{-1}$, the averaged maximum $\mathrm{N}_{2} \mathrm{O}$ concentrations at $\mathrm{B} 1$ and $\mathrm{I} 1$ were $1.74 \mathrm{mg} \mathrm{N} \mathrm{L}^{-1}$ (Fig. 1), which equates to $0.43 \mathrm{mg} \mathrm{N} \mathrm{kg}^{-1}$. This observation is in contrast to the findings of Well et al. (2003) who reported greater $\mathrm{N}_{2} \mathrm{O}$-fractions as a result of laboratory incubation in most of the investigated soils. Blicher-Mathiesen and Hoffmann (1999) also observed higher $\mathrm{N}_{2} \mathrm{O}$ concentrations during their laboratory experiments due to a differing reduction pattern that supported $\mathrm{N}_{2} \mathrm{O}$ accumulation. Another disagreement between laboratory and field data is evident from the increasing $c \mathrm{~N}_{2} \mathrm{O}_{\text {max }}$ values of $\mathrm{N}_{2} \mathrm{O}$ with depth during laboratory incubation (Fig. 2), whereas the field data indicate the highest $\mathrm{N}_{2} \mathrm{O}$ accumulation in the uppermost groundwater (Fig. 1b; Deurer et al., 2008).

What are the reasons causing the poorer transferability of the "heterotrophic" incubations to the field scale related to the kinetics of $\mathrm{N}_{2} \mathrm{O}$ production and recuction? One explanation could be that the aquifer slurries are subject to a certain disturbance for a short time according to the laboratory method, i.e. physical disruption, storage, and aerobic conditions during collection. This may alter the conditions for the microbial communities. For example, Laverman et al. (2010) reported that homogenized sediment slurries support higher denitrification rates compared to intact sediment "flow-through reactors", due to an increase in the contact between microorganisms and the substrate. Another aspect is the difference in $\mathrm{O}_{2}$ concentrations. Whereas $\mathrm{O}_{2}$ concentrations were elevated in the near-surface groundwater (Fig. 1e), the laboratory incubations were carried out under anoxic conditions. We assume that the "intermediate" $\mathrm{O}_{2}$ concentrations in the groundwater (Deurer et al., 2008) contribute to the considerable in situ $\mathrm{N}_{2} \mathrm{O}$ accumulation, whereas anoxic 
conditions present during the laboratory incubation experiment possibly supported a further reduction of $\mathrm{N}_{2} \mathrm{O}$ to $\mathrm{N}_{2}$. Thus, the transferability of the results obtained from the laboratory incubations to the in situ conditions should be interpreted with care for the heterotrophic denitrification zone. In fact, the influence of the mentioned processes seemed to be negligible in the case of autotrophic denitrification, because the laboratory incubations reflected the field data. This might be explained by the high abundance of pyrite that seems to be easily accessible to the autotrophic denitrifier Thiobacillus denitrificans (Böttcher et al., 1991) and by the fact that the electron donor was not sustainably altered by temporal contamination with atmospheric oxygen and physical disturbances during sampling. To the contrary, we assume that the small pool of available organic carbon in the heterotrophic zone might be sensitive to disturbances, e.g. by oxidation with atmospheric oxygen. This could lead to some loss of denitrification capacity and might explain the observed deviations in $\mathrm{N}_{2} \mathrm{O}$ accumulation. Another reason for the discrepancy between laboratory and field-based studies was reported by Smith et al. (1996). The authors identified the differences between spatial and temporal scales as a reason for this discrepancy. Furthermore, sampling of a small amount of aquifer slurry for laboratory incubations may miss patches and hotspots of available organic carbon and heterotrophic denitrification activity (Jacinthe et al., 1998). Finally, in situ $\mathrm{N}_{2} \mathrm{O}$ accumulation in the heterotrophic zone is affected by the fluctuating groundwater level and day-scale infiltration events. These dynamics are not provided by static incubation experiments. To sum up, we note that the kinetics of $\mathrm{N}_{2} \mathrm{O}$ production and reduction in the heterotrophic denitrification zone tends to be susceptible to effects connected with sampling and the static laboratory approach conducted at the microscale. In contrast, the autotrophic denitrification seems to be a more robust process. The availability of its uniformly distributed electron donor as well as anoxic conditions induce high denitrification activity which hampers changes of in situ processes and reaction kinetics during laboratory investigations yielding a good agreement of field and laboratory results.

\section{Conclusions}

$\mathrm{N}_{2} \mathrm{O}$ is produced in the near-surface groundwater of the FFA as an intermediate of heterotrophic denitrification as well as in depths beyond $2-3 \mathrm{~m}$ below the groundwater table due to autotrophic denitrification. The heterotrophic process is limited by the availability of the electron donor organic carbon, low $\mathrm{pH}$, and oxic conditions, yielding a low denitrification capacity. Field measurements indicated considerable $\mathrm{N}_{2} \mathrm{O}$ accumulation especially in the uppermost groundwater. In contrast, laboratory incubations of aquifer material showed substantially lower $\mathrm{N}_{2} \mathrm{O}$ concentrations than measured in the field. Thus, the transferability of the laboratory results to the field scale is limited. We conclude that the discrepancy between field and laboratory conditions is due to the susceptibility of the sensitive heterotrophic process to sampling activities, storage of aquifer material, different $\mathrm{O}_{2}$ levels and differences in spatial scales. The autotrophic process is characterised by a high denitrification capacity and not limited by its electron donor pyrite and the presence of oxygen, respectively. Laboratory and field data were found to be in good agreement showing that the autotrophic zone functions as a sink for $\mathrm{N}_{2} \mathrm{O}$. The application of a conventional $k_{1}-k_{2}-$ model following first-order-kinetics revealed rate constants that roughly confirmed the experimental data, i.e. for example the difference between the reaction rates of heterotrophic and autotrophic denitrification. However, the fitting results to the experimental time courses of the $\mathrm{N}$-species were partly unsatisfactory. In conclusion, we note that a more sophisticated approach will be useful to describe the kinetics of $\mathrm{N}_{2} \mathrm{O}$ production and reduction more properly.

Acknowledgements. Financial support from the German Research Foundation (DFG) is gratefully acknowledged. We thank I. Ostermeyer and K. Schmidt for their assistance in the laboratory and L. Szwec and R. Langel (Centre for Stable Isotope Research and Analysis, University of Göttingen) for the stable isotope analyses. Sampling would not have been possible without the help of G. Klump and the drilling crew from the Federal Institute for Geosciences and Natural Resources in Hannover. Finally, we thank J. Böttcher and W. Duijnisveld for fruitful discussions and two anonymous reviewers for their constructive comments within the open discussion process.

Edited by: T. J. Battin

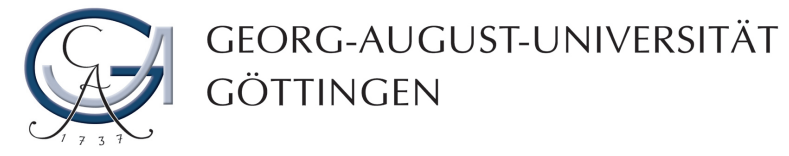

This Open Access Publication is funded by the University of Göttingen.

\section{References}

Ambus, P. and Lowrance, R.: Comparison of denitrification in two riparian soils, Soil Sci. Soc. Am. J., 55, 994-997, 1991.

Blackmer, A. M. and Bremner, J. M.: Inhibitory effect of nitrate on reduction of nitrous oxide to molecular nitrogen by soil microorganisms, Soil Biol. Biochem., 10, 187-191, 1978.

Blicher-Mathiesen, G. and Hoffmann, C. C.: Denitrification as a sink for dissolved nitrous oxide in a freshwater riparian fen, J. Environ. Qual., 28, 257-262, 1999.

Böttcher, J., Strebel, O., and Duijnisveld, W. H. M.: Kinetik und Modellierung gekoppelter Stoffumsetzungen im Grundwasser eines Lockergesteins-Aquifers, Geol. Jahrb. Reihe C, 51, 3-40, 1989. 
Böttcher, J., Strebel, O., Duijnisveld, W. H. M., and Frind, O.: Reply (to a comment of Scott F. Korom), Water Resour. Res., 27, 3275-3278, 1991.

Böttcher, J., Strebel, O., and Kölle, W.: Redox conditions and microbial sulfur reactions in the Fuhrberger Feld sandy aquifer, in: Progress in Hydrogeochemistry, edited by: Matthess, G., Frimmel, F. H., Hirsch, P., Schulz, H. D., and Usdowski, E., Springer, Berlin and Heidelberg, 219-226, 1992.

Böttcher, J., Strebel, O., Vörkelius, S., and Schmidt, H.: Using isotope fractionation of nitrate-nitrogen and nitrate-oxygen for evaluation of microbial denitrification in a sandy aquifer, J. Hydrol., 114, 413-424, 1990.

Clough, T. J., Addy, K., Kellog, D. Q., Nowicki, B. L., Gold, A. J., and Groffman, P. M.: Dynamics of nitrous oxide in groundwater at the aquatic-terrestrial interface, Global Change Biol., 13, 1528-1537, 2007.

Clough, T. J., Sherlock, R. R., and Rolston, D. E.: A review of the movement and fate of $\mathrm{N}_{2} \mathrm{O}$ in the subsoil, Nutr. Cycl. Agroecosys., 72, 3-11, 2005.

Davidson, E. A., Matson, P. A., Vitousek, P. M., Riley, R., Dunkin, K., Garcia-Mendez, G., and Maass, J. M.: Process regulating soil emission of $\mathrm{NO}$ and $\mathrm{N}_{2} \mathrm{O}$ in a seasonally dry tropical soil, Ecology, 74, 130-139, 1993.

Deurer, M., von der Heide, C., Böttcher, J., Duijnisveld, W. H. M., Weymann, D., and Well, R.: The dynamics of $\mathrm{N}_{2} \mathrm{O}$ in the surface groundwater and its transfer into the unsaturated zone: A case study from a sandy aquifer in Germany, Catena, 72, 362-373, 2008.

Dykaar, B. and Kitanides, P.: Macrotransport of biologically reacting solute through porous media, Water Resour. Res., 32, 302320, 1996.

Firestone, M. K. and Davidson, E. A.: Microbiological basis of $\mathrm{NO}$ and $\mathrm{N}_{2} \mathrm{O}$ production and consumption in soil, in: Exchange of Trace Gases between Terrestrial Ecosystems and the Atmosphere, edited by: Andreae, M. O. and Schimel, D. S., John Wiley and Sons, Chichester, 7-21, 1989.

Frind, E., Duijnisveld, W. H. M., Strebel, O., and Böttcher, J.: Modeling of multicomponent transport with microbial transformation in groundwater: The Fuhrberg case, Water Resour. Res., 26, 1707-1719, 1990.

Geistlinger, H., Jia, R., Eisermann, D., and Stange, C. F.: Spatial and temporal variability of dissolved nitrous oxide in nearsurface groundwater and its correlation to dissolved oxygen and groundwater fluctuations, J. Plant Nutr. Soil Sc., in press, doi:10.1002/jpln.200800278, 2010.

Ginn, T. R., Wood, B. D., Nelson, K. E., Scheibe, T. D., Murphy, E. M., and Clement, T. P.: Processes in microbial transport in the natural subsurface, Adv. Water Resour., 25, 1017-1042, 2002.

Gold, A. J., Jacinthe, P. A., Groffman, P. M., Wright, W. R., and Puffer, R. H.: Patchiness in groundwater nitrate removal in a riparian forest, J. Environ. Qual., 27, 146-155, 1998.

Grant, R. F. and Pattey, E.: Modelling variability in $\mathrm{N}_{2} \mathrm{O}$ emissions from fertilized agricultural fields, Soil Biol. Biochem., 35, 225243, 2003.

Groffman, P. M., Gold, A. J., and Jacinthe, P. A.: Nitrous oxide production in riparian zones and groundwater, Nutr. Cycl. Agroecosys., 52, 179-186, 1998.
Groffman, P. M., Howard, P., Gold, A. J., and Nelson, W. M.: Microbial nitrate processing in shallow groundwater in a riparian forest, J. Environ. Qual., 25, 1309-1316, 1996.

Hack, J. and Kaupenjohann, M.: $\mathrm{N}_{2} \mathrm{O}$ discharge with drain water from agricultural soils of the upper Neckar region in Southern Germany, in: Non- $\mathrm{CO}_{2}$ Greenhouse Gases: Scientific understanding, control options and policity aspects, edited by: van Ham, J., Baede, A. P. M., Guicherit, R., and Williams-Jacobse, J. G. F. M., Millpress, Rotterdam, 185-190, 2002.

Hansen, C.: Entwicklung und Anwendung hydrogeochemischer Stoffflussmodelle zur Modellierung der Grund- und Rohwasserqualität in Grundwasser-Gewinnungsanlagen- Fallbeispiel Fuhrberger Feld-, Clausthaler Geowissenschaften, 4: XII, Dissertation Univ. of Clausthal, Germany, 2005.

Hefting, M. M., Bobbink, R., and de Caluwe, H.: Nitrous oxide emission and denitrification in chronically nitrate-loaded riparian buffer zones, J. Environ. Qual., 32, 1194-1203, 2003.

Hefting, M. M., Bobbink, R., and Janssens, M. P.: Spatial variation in denitrification and $\mathrm{N}_{2} \mathrm{O}$ emission in relation to nitrate removal efficiency in a $\mathrm{N}$-stressed riparian buffer zone, Ecosystems, 9, 550-563, doi:10.1007/s10021-006-0160-8, 2006.

Heincke, M. and Kaupenjohann, M.: Effects of soil solution on the dynamics of $\mathrm{N}_{2} \mathrm{O}$ emissions: a review, Nutr. Cycl. Agroecosys., 55, 133-157, 1999.

Hénault, C., Chéneby, D., Heurlier, K., Garrido, F., Perez, S., and Germon, J. C.: Laboratory kinetics of soil denitrification are useful to discriminate soils with potentially high levels of $\mathrm{N}_{2} \mathrm{O}$ emission on the field scale, Agronomie, 21, 713-723, 2001.

Hiscock, K. M., Bateman, A. S., Mühlherr, I. H., Fukada, T., and Dennis, P. F.: Indirect emissions of nitrous oxide from regional aquifers in the United Kingdom, Environ. Sci. Technol., 37, 3507-3512, 2003.

Hoehener, P., Duwig, C., Pasteris, G., Kaufmann, K., Dakhel, N., and Hauke, H.: Biodegradation of petroleum hydrocarbon vapors: laboratory studies on rates and kinetics in unsaturated alluvial sand, J. Contam. Hydrol., 66, 93-115, 2003.

Holtan-Hartwig, L., Dörsch, P., and Bakken, L. R.: Comparison of denitrifying communities in organic soils: kinetics of $\mathrm{NO}_{3}^{-}$and $\mathrm{N}_{2} \mathrm{O}$ reduction, Soil Biol. Biochem., 32, 833-843, 2000.

Holtan-Hartwig, L., Dörsch, P., and Bakken, L. R.: Low temperature control of soil denitrifying communities: kinetics of $\mathrm{N}_{2} \mathrm{O}$ production and reduction, Soil Biol. Biochem., 34, 1797-1806, 2002.

Intergovernmental Panel on Climate Change (IPCC): 2006 IPCC guidelines for national greenhouse gas inventories, Prepared by the National Greenhouse Gas Inventories Programme, edited by: Egglestone, H. S., Buendia, L., Miwa, K., Ngara, T., and Tanabe, K., IGES, Japan, 2006.

Jacinthe, P. A., Groffman, P. M., Gold, A. J., and Mosier, A.: Patchiness in microbial nitrogen transformations in groundwater in a riparian forest, J. Environ. Qual., 27, 156-164, 1998.

Kelly, W. R., Hornberger, G. M., Herman, J. S., and Mills, A. L.: Kinetics of BTX biodegradation and mineralization in batch and column systems, J. Contam. Hydrol., 23, 113-132, 1996.

Kölle, W., Strebel, O., and Böttcher, J.: Formation of sulfate by microbial denitrification in a reducing aquifer, Water Supp., 3, 35-40, 1985. 
Kölle, W., Werner, P., Strebel, O., and Böttcher, J.: Denitrifikation in einem reduzierenden Grundwasserleiter, Vom Wasser, 61, 125-147, 1983.

Konrad, C.: Methoden zur Bestimmung des Umsatzes von Stickstoff, dargestellt für drei pleistozäne Grundwasserleiter Norddeutschlands, Ph.D. thesis, Dresden University of Technology, Germany, 157 pp., 2007.

Korom, S. F.: Comment on "Modeling of multicomponent transport with microbial transformation in groundwater: The Fuhrberg case" by Frind, E., Duijnisveld, W. H. M., Strebel, O., and Böttcher, J., Water Resour. Res., 27, 3271-3274, 1991.

Korom, S. F.: Natural denitrification in the saturated zone: a review, Water Resour. Res., 28, 1657-1668, 1992.

Laverman, A. M., Garnier, J. A., Mounier, E. M., and RooseAmsaleg, C. L.: Nitrous oxide production kinetics during nitrate reduction in river sediments, Water Res., 44, 1753-1764, 2010.

McCarty, G. W. and Bremner, J. W.: Availability of organic carbon for denitrification of nitrate in subsoils, Biol. Fert. Soils, 14, 219 222, 1992

McQuarrie, K. T. B. and Sudicky, E. A.: Multicomponent simulation of wastewater-derived nitrogen and carbon in shallow unconfined aquifers, I. Model formulation and performance, J. Contam. Hydrol., 47, 53-84, 2001

Mosier, A. R., Kroeze, C., Nevison, C., Oenema, O., Seitzinger, S. P., and van Cleemput, O.: Closing the global $\mathrm{N}_{2} \mathrm{O}$ budget: nitrous oxide emissions through the agricultural nitrogen cycle, Nutr. Cycl. Agroecosys., 52, 225-248, 1998.

Mühlherr, I. H. and Hiscock, K. M.: Nitrous oxide production and consumption in British limestone aquifers, J. Hydrol., 211, 126139, 1998.

Nõmmik, H.: Investigations on denitrification in soil, Acta Agr. Scand., 6, 195-228, 1956

Obenhuber, D. C. and Lowrance, R.: Reduction of nitrate in aquifer microcosms by carbon additions, J. Environ. Qual., 20, 255-258, 1991.

Paramasivam, S., Alva, A. K., Prakash, O., and Cui, S. L.: Denitrification in the vadose zone and in surficial groundwater of a sandy entisol with citrus production, Plant Soil, 208, 307-319, 1999.

Parkin, T. B.: Soil microsites as a source of denitrification variability, Soil Sci. Soc. Am. J., 51, 1194-1199, 1987.

Pätsch, M.: Analyse des Nitratumsatzes und dessen Heterogenität im quartären Grundwasserleiter des Wasserwerkes Thülsfelde - Berücksichtigung bei der Modellierung des Transportes, Ph.D. thesis, Dresden University of Technology, Germany, 223 pp., 2006.

Reay, D. S., Smith, K. A., and Edwards, A. C.: Nitrous oxide emission from agricultural drainage waters, Global Change Biol., 9, 195-203, 2003.

Rice, C. W. and Rogers, K. L.: Denitrification in subsurface environments: Potential source for atmospheric nitrous oxide, in: Agricultural ecosystems effects on trace gases and global climate change, ASA special publications, edited by: Harper, L. A., Mosier, A. R., Duxbury, J. M., and Rolston, D. E., American Society of Agronomy, Crop Science Society of America and Soil Science Society of America, Madison, 121-132, 1993.

Rivett, M. O., Buss, S. R., Morgan, P., Smith, J. W. N., and Bemment, C. D.: Nitrate attenuation in groundwater: A review of biogeochemical controlling processes, Water Res., 42, 4215-4232, 2008.
Russow, R., Sich, I., and Neue, H. U.: The formation of the trace gases $\mathrm{NO}$ and $\mathrm{N}_{2} \mathrm{O}$ in soils by the coupled processes of nitrification and denitrification: results of kinetic ${ }^{15} \mathrm{~N}$ tracer investigations, Chemosphere, 2, 359-366, 2000.

Russow, R., Spott, O., and Stange, C. F.: Evaluation of nitrate and ammonium as sources of $\mathrm{NO}$ and $\mathrm{N}_{2} \mathrm{O}$ emissions from Black Earth soils (Haplic Chernozem) based on ${ }^{15} \mathrm{~N}$ field experiments, Soil Biol. Biochem., 40, 380-391, 2008.

Schirmer, M., Molson, J. W., Frind, E. O., and Barker, J. F. Biodegradation modelling of a dissolved gasoline plume applying independent laboratory and field parameters, J. Contam. Hydrol., 46, 339-374, 2000.

Schlichting, E., Blume, H. P., and Stahr, K.: Bodenkundliches Praktikum, Blackwell Wissenschaft, Berlin, Germany, 1995.

Siemens, J., Haas, M., and Kaupenjohann, M.: Dissolved organic matter induced denitrification in subsoils and aquifers?, Geoderma, 113, 253-271, 2003.

Šimek, M. and Cooper, J. E.: The influence of soil pH on denitrification: progress towards the understanding of this interaction over the last 50 years, Eur. J. Soil Sci., 53, 345-354, 2002.

Skiba, U., Fowler, D., and Smith, K. A.: Nitric oxide emissions from agricultural soils in temperate and tropical climates: sources, controls and mitigation options, Nutr. Cycl. Agroecosys., 48, 139-153, 1997.

Smith, R. L. and Duff, J. H.: Denitrification in a sand and gravel aquifer, Appl. Environ. Microbiol., 54, 1071-1078, 1988

Smith, R. L., Garabedian, S. P., and Brooks, M. H.: Comparison of denitrification activity measurements in groundwater using cores and natural-gradient tracer tests, Environ. Sci. Technol., 30, 3448-3456, 1996.

Spalding, R. F., Gormly, J. R., and Nash, K. G.: Carbon contents and sources in ground waters of the central Platte region in $\mathrm{Ne}$ braska, J. Environ. Qual., 7, 428-434, 1978.

Spalding, R. F. and Parrott, J. D.: Shallow groundwater denitrification, Sci. Total Environ., 141, 17-25, 1994.

Tiedje, J. M.: Denitrifiers, in: Methods of Soil Analysis, Part 2, Microbiological and Biochemical Properties, edited by: Weaver, R. W., Angle, J. S., and Bottomley, P. J., SSSA, Madison, WI, USA, 245-267, 1994

van Cleemput, O.: Subsoils: chemo- and biological denitrification, $\mathrm{N}_{2} \mathrm{O}$ and $\mathrm{N}_{2}$ emissions, Nutr. Cycl. Agroecosys., 52, 187-194, 1998.

von der Heide, C., Böttcher, J., Deurer, M., Weymann, D., Well, R., and Duijnisveld, W. H. M.: Spatial variability of $\mathrm{N}_{2} \mathrm{O}$ concentrations and of denitrification-related factors in the surficial groundwater of a catchment in Northern Germany, J. Hydrol., 360, 230-241, 2008.

von der Heide, C., Böttcher, J., Deurer, M., Duijnisveld, W. H. M., Weymann, D., and Well, R.: Estimation of indirect $\mathrm{N}_{2} \mathrm{O}$ emissions from a shallow aquifer: a case study in northern Germany, J. Environ. Qual., 38, 2161-2171, 2009.

von der Heide, C., Böttcher, J., Deurer, M., Duijnisveld, W. H. M., Weymann, D., and Well, R.: Spatial and temporal variability of $\mathrm{N}_{2} \mathrm{O}$ in the surface groundwater: a detailed analysis from a sandy aquifer in northern Germany, Nutr. Cycl. Agroecosys., 87(1), 33 47, doi:10.1007/s10705-009-9310-7, 2010.

Weiss, R. F.: The solubility of nitrogen, oxygen and argon in water and sea water, Deep-Sea Res., 17, 721-735, 1970. 
Weiss, R. F. and Price, B. A.: Nitrous oxide solubility in water and sea water, Mar. Chem., 8, 347-359, 1980.

Well, R., Augustin, J., Meyer, K., and Myrold, D. D.: Comparison of field and laboratory measurement of denitrification and $\mathrm{N}_{2} \mathrm{O}$ production in the saturated zone of hydromorphic soils, Soil Biol. Biochem., 35, 783-799, 2003.

Well, R., Becker, K. W., Langel, R., Meyer, B., and Reineking, A.: Continuous flow equilibration for mass spectrometric analysis of dinitrogen emissions, Soil Sci. Soc. Am. J., 62, 906-910, 1998.

Well, R., Flessa, H., Jaradat, F., Toyoda, S., and Yoshida, N.: Measurement of isotopomer signatures of $\mathrm{N}_{2} \mathrm{O}$ in groundwater, J. Geophys. Res., 110, G02006, doi:10.1029/2005JG000044, 2005a.

Well, R., Höper, H., Mehranfar, O., and Meyer, K.: Denitrification in the saturated zone of hydromorphic soils - laboratory measurement, regulating factors and stochastic modeling, Soil Biol. Biochem., 37, 1822-1836, 2005 b.
Well, R. and Myrold, D. D.: Laboratory evaluation of a new method for in situ measurement of denitrification in water-saturated soils, Soil Biol. Biochem., 31, 1109-1119, 1999.

Weymann, D., Well, R., von der Heide, C., Flessa, H., Böttcher, J., and Duijnisveld, W. H. M.: Recovery of groundwater $\mathrm{N}_{2} \mathrm{O}$ at the soil surface and its contribution to total $\mathrm{N}_{2} \mathrm{O}$ emissions, Nutr. Cycl. Agroecosys., 85, 299-312, 2009.

Weymann, D., Well, R., Flessa, H., von der Heide, C., Deurer, M., Meyer, K., Konrad, C., and Walther, W.: Groundwater $\mathrm{N}_{2} \mathrm{O}$ emission factors of nitrate-contaminated aquifers as derived from denitrification progress and $\mathrm{N}_{2} \mathrm{O}$ accumulation, Biogeosciences, 5, 1215-1226, doi:10.5194/bg-5-1215-2008, 2008. 